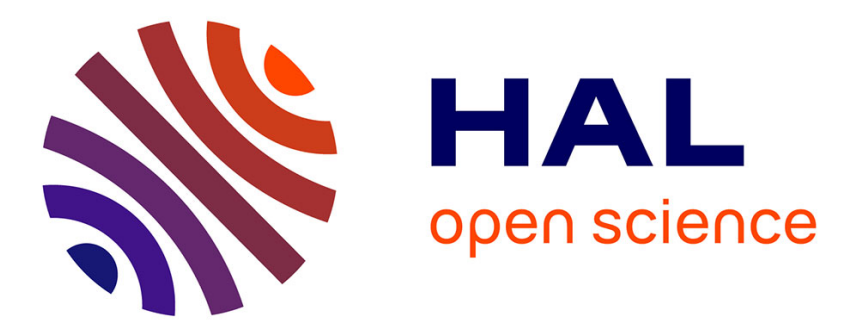

\title{
High interannual variability of a climate-driven amphibian community in a seasonal rainforest
}

Nicolas Dubos, Loïs Morel, Angelica Crottini, Karen Freeman, Jean Honoré, Honoré Lava, Jean Noël, Ingrid Porton, Georges Rendrirendry, Gonçalo M

Rosa, et al.

\section{To cite this version:}

Nicolas Dubos, Loïs Morel, Angelica Crottini, Karen Freeman, Jean Honoré, et al.. High interannual variability of a climate-driven amphibian community in a seasonal rainforest. Biodiversity and Conservation, 2020, 29 (3), pp.893-912. 10.1007/s10531-019-01916-3 . hal-02962314

\section{HAL Id: hal-02962314 https: / hal.sorbonne-universite.fr/hal-02962314}

Submitted on 12 Nov 2020

HAL is a multi-disciplinary open access archive for the deposit and dissemination of scientific research documents, whether they are published or not. The documents may come from teaching and research institutions in France or abroad, or from public or private research centers.
L'archive ouverte pluridisciplinaire HAL, est destinée au dépôt et à la diffusion de documents scientifiques de niveau recherche, publiés ou non, émanant des établissements d'enseignement et de recherche français ou étrangers, des laboratoires publics ou privés. 


\section{High interannual variability of a climate-driven amphibian community in a seasonal rainforest}

Nicolas Dubos ${ }^{1,2}$, Loïs Morel $^{3}$, Angelica Crottini ${ }^{4}$, Karen Freeman ${ }^{5}$, Jean Honoré ${ }^{5}$ Honoré Lava $^{5}$, Jean Noël ${ }^{5}$, Ingrid Porton ${ }^{5}$, Georges Rendrirendry ${ }^{5}$, Gonçalo M. Rosa ${ }^{6,7}$, Franco Andreone ${ }^{2}$

1 Centre d'Ecologie et des Sciences de la Conservation (CESCO UMR 7204), Centre de Recherches sur la Biologie des Populations d'Oiseaux (CRBPO), Sorbonne Universités, MNHN, CNRS, Paris, France

2 Museo Regionale di Scienze Naturali, Via G. Giolitti, 36, I-10123, Torino, Italy

${ }^{3}$ Géoarchitecture: Territoires, Urbanisation, Biodiversité, Environnement (EA 7462 G-TUBE), Université de Rennes 1, Université de Bretagne Occidentale, Campus de Beaulieu, 35042 Rennes, France

${ }^{4}$ CIBIO, Research Centre in Biodiversity and Genetic Resources, InBIO, Universidade do Porto, Campus Agrário de Vairão, Rua Padre Armando Quintas, No 7, 4485-661 Vairão, Portugal

5 Madagascar Fauna and Flora Group, BP442, Toamasina 501, Madagascar

6 Institute of Zoology, Zoological Society of London, Regent's Park, NW1 4RY, London, UK

${ }^{7}$ Centre for Ecology, Evolution and Environmental Changes (CE3C), Faculdade de Ciências da Universidade de Lisboa, Campo Grande, 1749-016 Lisboa, Portugal

Corresponding author:

Nicolas Dubos <dubos.research@gmail.com>

http://orcid.org/0000-0002-1224-2598 


\section{Abstract}

Seasonality exerts strong pressures on biodiversity patterns. Yet, temporal beta-diversity is poorly studied in tropical systems, and the drivers of variability in amphibian activity and seasonality remain largely unknown. We quantified intra- and interannual variation in temporal beta-diversity relying on a nine-year, year-round survey (51 species, $n>23000$ ) performed in a protected area (Betampona, Madagascar). We assessed the dependence on climate of beta-diversity and abundance using a distance-based redundancy analysis and generalised linear mixed models, respectively. Despite the majority of species being preferentially active during one specific period, beta-diversity and abundance were more variable between years than within years. Temporal variation in beta-diversity was best explained by temperature (but climate accounted for only $2 \%$ of variation). Species abundance was best explained by temperature (for $32 \%$ of the tested species), monthly humidity (30\%) and monthly rainfall (24\%). We found no climatic dependence for $24 \%$ of the species. Our results suggest that studies focusing on species phenology can be misleading when based on single-year surveys even in seasonal systems. The high interannual variability in diversity may be due to an adaptive responses to an important regime of stochastic events. Given the direction of the relationships between weather and abundances, we predict that a large proportion of amphibians would suffer from climate change in Madagascar. We emphasise the need to account for multiple temporal scales in studies of tropical species composition and abundance to better understand species phenology and their response to climate change, and make targeted conservation actions more effective. 
Key-words: Madagascar, Phenology, Rainforest anurans, Reserve Naturelle Intégrale de Betampona, Temporal beta-diversity, Weather. 


\section{Introduction}

Seasonality, the cyclical predictability of temperature, rainfall and available resources, is a major component of environmental variation which strongly shapes many aspects of biodiversity such as community structure and composition (Tonkin et al. 2017), and population dynamics (Sparks and Carey 1995). While spatial patterns of Beta-diversity (i.e., the component of regional diversity that accumulates as a result of differences between sites) are comparatively well studied (Socolar et al. 2016), the patterns of temporal beta-diversity (i.e., differences between species assemblages at different periods) is still poorly known both in temperate and in tropical areas. This is due, in part, to studies examining temporal variability in species composition focusing on within-year variability (i.e., seasonality). Although community composition can exhibit substantial variation between years (e.g., Gómez-Rodríguez et al. 2010), most surveys in tropical systems are limited to one year (e.g., Andreone 1994, 1996, Bertoluci and Rodrigues 2002, Gottsberger and Gruber 2004, Lopez et al. 2011, Heinermann et al. 2015).

Ectothermic organisms such as amphibians mostly rely on external conditions for their physiological state and hence, their seasonal activity patterns, reproductive periods, and population dynamics (Wells 2010; Segev et al. 2012). Understanding species' activity patterns and phenology is crucial for planning targeted conservation and management actions (e.g., Heinermann et al. 2015), but also allows for the detection of putative shifts in response to unusual weather events and/or climate change (e.g., Visser and Both 2005, Moussus et al. 2009). Despite its importance for research and conservation, there have been few long-term studies assessing amphibian seasonality (see also Prado et al. 2005, Saenz et al. 2006) and little is known about between-year variability in species' activity patterns and community 
composition on tropical amphibian activity patterns, particularly in biodiversity-rich places such as Madagascar (Gross 2019).

The impact of environmental conditions on amphibian temporal diversity can be observed at two levels: the community level (through changes in species composition; Tonkin et al. 2017), and the population level (through effects on species activity; Segev et al. 2012). Most studies identified temperature (Bertoluci and Rodrigues 2002, Saenz et al. 2006, Schalk and Saenz 2016, Segev et al. 2012), rainfall (Duellman 1995; Bevier 1997; Gottsberger and Gruber 2004; Schalk and Saenz 2016) and humidity (Heinermann et al. 2015) as important drivers of amphibian species activity. Temporal activity may also be driven by intrinsic factors, with species exhibiting consistent peaks of activity between years (Duellman and Trueb 1994). Activity peaks of Malagasy amphibians are often centred within the warm and wet season (Glaw and Vences 2007), which in Madagascar extends from October to April and coincides with breeding events for most species. Amphibian activity patterns are often characterised by strong variations between and within species. For instance, several species may exhibit a peak of activity during the dry-cold season (Glaw and Vences 1996), while others are active and breed continuously through the year (Crump 1974). To better understand the phenology of amphibians that inhabit Madagascar's eastern rainforests, there is an urgent need to formally assess the (1) timing, (2) duration, and (3) climatic dependence of each species' activity.

Here we present our analysis of temporal variations in (a) species composition and abundance at the community level, and (b) individual species abundances (population level), based on nine years of a year-round survey carried out at the "Réserve Naturelle Intégrale de Betampona" (from here onwards "Betampona"), in eastern Madagascar (Rosa et al., 2012). As the climate in our system follows a seasonal rhythm in terms of temperature and precipitation 
(Fig. 1c, d), we expected a marked seasonality in species composition and abundance, with little variation between years. We propose a classification of species through selection of aspects of their activity patterns (i.e., period, duration, and climatic drivers), and provide recommendations for the development of monitoring and management programs.

\section{Material and Methods}

\section{STUDY SITE}

Most of Madagascar's amphibian diversity is found on the eastern rainforest coastal band (Green and Sussman 1990; Brown et al. 2016). Betampona is an isolated 2,228 hectare lowland rainforest fragment located approximately $40 \mathrm{~km}$ northwest of Toamsina (Fig. S1). It extends from 92 to $571 \mathrm{~m}$ above sea level (Ghulam 2014) and is characterised by a tropical rainforest climate (Peel et al. 2007). Betampona is managed by Madagascar National Parks (MNP) and the Madagascar Fauna and Flora Group (MFG) serves as MNP's research partner. In that role, the MFG has encouraged and facilitated long-term research focused on the reserve's incredibly rich frog community, which has led to an increasing number of scientific contributions over the past decade (Andreone et al. 2010; Rosa et al. 2011; Rosa et al. 2012; Rosa et al. 2014; Bellati et al. 2018). More recent surveys have revised Betampona's species list that now includes over 80 frog species (A. Crottini, pers. obs.). Based on previous inventory efforts in Betampona, we selected two amphibian-rich sites to establish long-term monitoring transects for amphibians, locally known as "Sahabefoza" (S 17 54' 51.2"; E 049 12' 27.7") and "Sahambendrana" (S 17 53' 54.2”; E $049^{\circ} 12$ ' 55.4”).

\section{CLIMATIC DATA}


Betampona's tropical climate is characterised by a marked seasonality in terms of temperature and precipitation (Fig. 1c, d), with lower temperatures $\left(23.0^{\circ} \mathrm{C} \pm 3.0 \mathrm{SD}\right)$ and precipitation (5.2 mm.day ${ }^{-1} \pm 10.2 \mathrm{SD}$ ) during winter (May to August, included) and higher temperatures $\left(28.3^{\circ} \mathrm{C} \pm 1.7 \mathrm{SD}\right)$ and precipitation $\left(10.1 \mathrm{~mm}\right.$. day $\left.^{-1} \pm 17.0 \mathrm{SD}\right)$ during summer (October to April). We define two additional seasons, following Heinermann et al. (2015): early spring (September - October), characterised by intermediate temperatures $\left(24.3^{\circ} \mathrm{C} \pm 2.1 \mathrm{SD}\right)$ and low precipitation $\left(3.4 \mathrm{~mm}\right.$. day $\left.^{-1} \pm 6.0 \mathrm{SD}\right)$; and late spring (November - December), characterised by high temperatures $\left(27.6^{\circ} \mathrm{C} \pm 2.4 \mathrm{SD}\right)$ and low precipitation $\left(3.8 \mathrm{~mm} . \mathrm{day}^{-1} \pm\right.$ 7.6 SD).

We obtained daily maximum and minimum records of temperature and humidity, and daily rainfall from the MFG field station at the southwest entrance of the reserve, locally known as "Rendrirendry". We computed daily mean temperature and humidity as the average between the maximum and minimum of daily records. To avoid collinearity, we only included uncorrelated variables (Pearson's $|\mathrm{r}|<0.70$; Table S1a in supporting information). For temperature, mean values were highly correlated to minimum and maximum values $(r>0.85)$, so hence we excluded the latter two. We also discarded maximum humidity, because this parameter showed little variation (mean $=0.93 \% \pm 0.04 \mathrm{SD})$. Because there may be a lag between trait expression and environmental variability (van de Pol and Cockburn 2011), we computed weekly (i.e., the seven preceding days) and monthly temperature and humidity as the mean of daily records, and weekly and monthly precipitation as the sum of daily records. We finally excluded daily, and monthly temperature, because they were highly correlated with weekly temperature $(r>0.90)$, and we kept the latter variable because it showed the highest variability. We also excluded weekly humidity (correlated with monthly humidity; $r=0.85$ ). 
The variables included in our analyses were: weekly mean temperature (referred to as “temperature"), daily and monthly mean humidity, and daily, weekly, and monthly sum precipitation (Fig. 1; Table S1b). To enable comparisons of their relative effects, all climatic variables were centred and scaled.

\section{SURVEYS}

We established six $500 \mathrm{~m}$ long transects regularly sampled during the period $2009-2017$, with each transect being completed three to 23 times per year. All transects were approximately equally represented throughout the dataset (between 55 and 61 sampling sessions per transect). Both "Sahabefoza" and "Sahambendrana" have a forest stream running through with a slope alongside. Three transects were installed at each site: (1) along the edge of the forest stream (hereafter "stream"), (2) parallel to the first transect but $30-50 \mathrm{~m}$ uphill ("slope") and (3) on the ridge top of the same slope ("ridge"). For each site a different transect was surveyed each night (between 6:30 pm and 9:30 pm) for three consecutive nights by one to four trained observers equipped with head-lamps and flashlights. The observers were all long-term employees of MFG with many years' proven experience at reliably identifying Betampona amphibian species. Initially (from July 2009 to September 2012) transects searches were carried out at both sites most months, but from October 2012 onwards, searches were limited to one site only per month. We noted date, observers, weather conditions, start, and end time of the surveys. Transects were walked at a steady speed of ca. $200 \mathrm{~m}$ per hour, taking note of all encountered amphibians.

In Betampona, twelve taxa are significantly genetically distinct from one or more species that are morphologically and ecologically very similar, and, therefore, are very difficult to 
distinguish from each other in the field (these are listed in supporting information; Appendix 1). Additionally, these complexes of species present similar activity patterns and thus, for survey and analysis purposes, we treated them as a single morpho-species (taxa marked with “£” in Table S2). Species identification follows Vieites et al. (2009) and Rosa et al. (2012).

\section{STATISTICAL ANALYSES}

We cross-tabulated field count data by species and day. As transects were not performed on the same dates, one cross-table was computed for each transect individually to limit zeroinflation. All statistical analyses were carried out under R version 3.5.2 (R Core Team 2018).

\section{Community level - quantifying temporal variability}

We assessed temporal changes in species composition and abundance (i.e. temporal betadiversity) of amphibian communities using two indices of dissimilarity: Jaccard' index for presence-absence data and Bray-Curtis for abundance data. Here we assume that one community corresponds to one transect at one site for one date, resulting in 350 communities. We first used Metric Multidimensional Scaling (MDS) ordinations to visualise pairwise dissimilarities of communities within each transect. Visualising beta-diversity within each transect separately enabled us to disentangle temporal patterns from topographical and spatial factors and allowed us to identify whether some ecological contexts induce more temporal variations in community composition. Secondly, we assessed whether community composition and abundance differed according to seasons and years, using Permutational Multivariate Analysis of Variance (PERMANOVAs). We performed marginal tests to 
determine the individual contribution of each variable to variation in community composition and abundance.

We then quantified the mean temporal beta-diversity within and between years by focusing on strict species turnover, calculated by multiple-site dissimilarities following the framework of Baselga (2010). The turnover index was independent of differences in species richness (Leprieur and Oikonomou 2013), so we strictly focused on species turnover in beta-diversity changes. To test for temporal differences in beta-diversity, we used linear mixed-effect models (LMMs), with sites and transects as random factors to account for spatial design. Betadiversity analyses were performed using the "betapart" and "vegan" R packages (Baselga and Orme 2012; Oksanen et al. 2015).

\section{Community level - climatic drivers of species composition and abundance}

We examined the influence of the six climatic variables selected (see above) on the Jaccard and the Bray-Curtis dissimilarity matrices using distance-based redundancy analysis (dbRDA). To improve the statistical power, we ran the db-RDAs over the entire dataset after removing communities for which we did not have climate data $(350-37=313$ communities studied). To account for spatial design and to focus on temporal beta-diversity, we constrained our model by two spatial factors (sites and transects).

\section{Population level - Activity duration}

We estimated species monthly abundances to classify species' activity duration following three categories: continuous, prolonged and sporadic (adapted from Wells 1977, Prado et al. 2005, Heinermann et al. 2015). Species activity duration was defined on the basis of the 
temporal dispersion of the number of observations ( $p$ ), following Heinermann et al. (2015). The temporal dispersion of observations was computed as the variance of monthly counts, expressed as the proportion of species total counts to control for differences in species abundance. As our survey encompassed several years, we computed $p$ only for the year with the highest number of recorded individuals, for each species separately. We defined activity duration classes according to the modalities found in the distribution frequency of species coefficients of variation. We assumed that the first modality represented species that are continuously active throughout the year, the second one represented species with prolonged activity, and the third one represented species for which the detection is sporadic (i.e., exhibiting a clear peak of activity). The low percentage of observations of some species during one sampling session - relative to the total number of observations - can produce high variances and impede characterisation of their overall activity pattern. Species, whose total number of observations during the year was fewer than 10 , were classified as "rare species".

\section{Population level - Preferred activity period}

We tested the effect of a four-level season factor (early spring, late spring, summer, winter; Heinermann et al. 2015) on species abundances. For each species separately, we used generalised linear mixed models (GLMMs; lme4 R package, version 1.1.12; Bates et al. 2015), assuming a Poisson distribution, with daily count as a response variable, and the season as the explanatory variable. A preferential season of activity was identified on the basis of the significance of parameter estimates. We controlled for confounding effects using the 
following adjustment variables: site and transect topography as factorial fixed effects, and observer groups and the year of observation as random effects.

\section{Population level - Climatic drivers of species abundance}

We investigated the relationships between species abundances and climatic variables using a multi-model inference approach (Johnson and Omland 2004). For each species individually, we used GLMMs assuming a negative binomial distribution, with daily count as a response variable, and the selected environmental variables (see above) as explanatory variables. We first built a full model that included all candidate variables. We accounted for the possibility of a non-linear effect of temperature by adding a quadratic effect. We then performed a model selection process, based on second order Akaike Information Criterion (AICc; Burnham and Anderson 2002). The model containing the effects with the highest statistical support receives the lowest value of AICc. Multi-model inference was implemented using the MuMIn R package version 1.42.1 (Barton 2018). The MuMIn function enables to build one model for each possible combination of all tested variables. The statistical support of a model $i$ was assessed by their AICc weight $\left(w_{i}\right)$. We retained all models where $\Delta \mathrm{AICc}<2$, to account for model selection uncertainty. We then used model averaging to produce the averaged parameter estimates and relative importance $\left(\Sigma w_{i}\right)$ of each parameter (Burnham and Anderson 2002). Models that are included in the best model set could include both the linear and the quadratic effect of a given variable, which can be misleading as the coefficient estimates would have a different biological meaning when the quadratic term is present or absent (Grueber et al. 2011). To account for this possibility, we re-performed the model selection process while removing the quadratic term for each of the 'best model sets' that included only 
a linear effect of temperature. We controlled for confounding effects by including the aforementioned adjustment variables in all models.

\section{Results}

We recorded a total of 23,427 individuals assigned to 51 taxa between 2009 and 2017 (Table S2). No data were collected for 18 species known to occur in Betampona. Those mostly correspond to species that are only occasionally found in the Reserve or are found only occasionally along the chosen transects.

\section{COMMUNITY LEVEL}

\section{Shifts in temporal beta-diversity}

Our analyses showed that amphibian community composition and abundance varied within and between the nine survey years (Figs $2-3$, Table. 1). On average, the shift in overall community composition (Jaccard dissimilarity) reached $0.64 \pm 0.18$ (mean \pm Standard deviation SD) within years and $0.70 \pm 0.08$ between the years; whereas the shift in overall community abundances (Bray-Curtis dissimilarity) reached $0.54 \pm 0.14$ and $0.59 \pm 0.10$, respectively (Fig. S2). Partitioning of temporal beta-diversity revealed that these changes were largely due to strict turnover rather than shifts in species richness: turnover and balanced variation accounted for $81 \%$ and $68 \%$ of the Jaccard and the Bray-Curtis within-year dissimilarities, and for $80 \%$ and $73 \%$ of between-years dissimilarities, respectively (Fig. S2).

Within years, no clear pattern of seasonality emerged onto the MDS spaces of the six studied transects (i.e., communities are not clustered by seasons; Fig. 2). Indeed, the 
PERMANOVA enabled the identification of significant variation in amphibian communities among seasons in only 1/6 transects for species composition (i.e., a stream transect; Table 1). In contrast, for abundance PERMANOVA identified significant variation in 4/6 transects. On the other hand, we found significant (or quasi-significant; $p<0.1$ ) differences between-years in community composition and abundance in most transects (5/6 and $6 / 6$, respectively).

Overall, the "year" factor explained a much larger proportion of variation in community composition and abundance compared to the 'season' factor $\left(R^{2}\right.$ ranged from 0.16 to 0.27 and 0.04 to 0.13 , respectively; Table 1). This is consistent with our assessment of changes in temporal beta-diversity: interannual variations in community composition and abundance were significantly higher than intra-annual variations (Wald's test, $\mathrm{p}<0.05$; Fig. S2). The MDS summarised $20.1-29.0 \%$ of the variance in the Jaccard dissimilarity matrices and 25.9 $-38.5 \%$ in the Bray-Curtis dissimilarity matrices (Fig. 2). Overall, the pairwise distances plotted onto the ordination space were proportional to the observed ones (indicated by the important alignment of data points; see Fig S3).

\section{Climatic drivers of community composition and abundance}

The climatic variables explained only a small amount of variation of community composition and abundance $(<2 \%$ of the total variation in both cases according to the db-RDAs). Out of the six climatic variables tested, only "weekly temperature" was significantly related to variation in community composition and abundance; nevertheless, "Monthly humidity" and "Monthly rain" were quasi-significantly related to variation in community composition (Table 2). 


\section{POPULATION LEVEL}

\section{Activity duration}

Among the 51 amphibian taxa, 23 (45\%) were active year-round, 11 (22\%) showed prolonged activity, one (Boophis albilabris; 2\%) was observed sporadically (Fig. 3, S4; Table S2) and 16 (25\%) were considered rare species.

\section{Activity period}

We modelled the abundances of 38 species (models could not converge for 13 species, with the lowest number of observations; Table S2). Nine species were significantly more present in a unique season (five during winter, one during early spring and three during summer), relative to all other seasons (Table S2; Fig. 3). The remaining 29 species were active during more than one season. During winter, early spring, late spring and summer respectively, 12, 10, 5 and 7 taxa were significantly more abundant relative to another season. No difference in abundance was detected between seasons for 16 species (see Fig. 3 for more details).

\section{Climatic drivers}

Temperature was the most important predictor of the abundance of $12(32 \%)$ species (negative effect for seven species, positive effect for five species), including nine for which the effect was robust ( $\Sigma w i=1.00$; negative for six species, positive for three species). Monthly humidity affected the abundances of $11(30 \%)$ species (negative for four species and positive for seven species), including nine for which the effect was robust (negative for two species and positive for seven species). Monthly rainfall affected nine (24\%) species (negative for 
three species and positive for six species), including six for which the effect was robust (negative for two species and positive for four species). Daily rainfall affected six (16\%) species, the effect was robust for three species. Daily humidity affected five (14\%) species (robust for four species). Nine (24\%) species did not appear to be affected by any of the climatic variables included in this study.

\section{Discussion}

Within-year variability versus between-year variability

The majority of species showed clear fluctuations in abundance between seasons (Fig. 3).

However, there is more variation in composition and abundance between years than between seasons. We only found a slight seasonality in beta-diversity along streams. This weak seasonality contrasts with previous studies performed in tropical seasonal environments where clearer patterns of amphibian activity emerged (Duellman 1995; Marques et al. 2001; Bertoluci and Rodrigues 2002; Kupfer et al. 2005; Prado et al. 2005; Gardner et al. 2007; dos Santos et al. 2009; Lopez et al. 2011; Vasconcelos et al. 2011; Segev et al. 2012; Schalk and Saenz 2016). Those studies were mostly performed in regions with marked seasonal precipitation. Although the average rainfall in Madagascar's eastern rainforests, including Betampona, is higher in the summer, precipitation is less variable within the year, with no real period of drought (Fig. 1). The marked seasonality in temperatures affects beta-diversity to a limited extent (Table 2), suggesting that variation in species composition is mainly driven by factors other than climate such as lunar phases (Grant et al. 2009; Vignoli et al., 2014) or stochastic processes (Baselga et al. 2015) such as extreme weather events. The high interannual variability in beta-diversity is consistent with previous studies performed in 
environments with low seasonality (Tonkin et al. 2017), or in environments that are characterised by highly unpredictable climatic conditions (Gómez-Rodríguez et al. 2010). Despite cyclones being more frequent in the austral summer, their occurrence is highly variable during the year (Ho et al. 2006). The high frequency of cyclonic disturbances influencing the eastern rainforest belt may constitute an important stochastic factor that shapes patterns of amphibian activity (Riemann et al. 2017). A weak expression of seasonality in rainforest amphibians may reflect an adaptive response to a high frequency of cyclones, towards more opportunistic strategies (Frederiksen et al. 2008; Tökölyi et al. 2012). In the absence of a consistent season associated with severe weather conditions, evolutionary pressure may not have selected for strategies of avoidance of unfavourable seasons such as hibernation or migration. Instead, unpredictable environments may rather select for adaptive plasticity, and the development of traits such as non-seasonal hibernation or opportunistic reproduction (Canale and Henry 2010). Another possible factor that could explain why species composition is more variable between years than within years is an asynchrony between species in biotic interactions. For some species, population dynamics may be regulated by density-dependent predator-prey, or pathogen-/parasite-host interactions (Whiteman and Wissinger 2005). Uncoupled fluctuations within the amphibian community would have driven important interannual variation in beta-diversity.

\section{Activity duration}

We found a high proportion of species with continuous activity (45\%), which strongly differs from Neotropical systems (i.e., between 11 and 16\%; Bertoluci and Rodrigues 2002; Prado et al. 2005). This is presumably due to the absence of a severe dry season in the eastern 
rainforest belt of Madagascar, enabling a large number of species to remain active year-round. This is consistent with the low proportion of sporadically active species (only one species out of 51, with a unique peak of activity: 41 individuals of B. albilabris recorded in only one day). This activity peak probably coincides with an explosive breeding event of this species and suggests that the proportion of explosive breeders is low compared to other amphibian communities in Madagascar (e.g., Glos 2003) or in other tropical areas (Bertoluci and Rodrigues 2002; Gottsberger and Gruber 2004; Prado et al. 2005). It is feasible that other explosive breeders were not detected during our surveys, and some of the species that here are classified as "rare" may be explosive breeders instead. Although activity can be related to breeding events, some species known as explosive breeders (e.g., Aglyptodactylus inguinalis) showed prolonged activity in this study (Table S2), suggesting that the proportion of explosive breeders may be underestimated. The formal identification of breeding strategies should be better assessed using calling activity, exhibition of secondary sexual characters, and observation of amplexus and tadpoles (e.g., Schalk and Saenz 2016). Hence, comparisons with other studies focusing on amphibian breeding activity must be treated with caution. Even taking into account this likely underestimation, the proportion of explosive breeders seems to be lower along the eastern rainforest of Madagascar in comparison with other tropical sites (e.g. Pantanal, Brazil; Prado et al. 2005). Heinermann et al. (2015) found a higher proportion of sporadically active species in eastern Madagascar, but they recorded only one clear peak of activity, and the remaining species were rather rare ( $\leq 10$ individuals). Explosive breeding strategies are usually driven by the presence of non-permanent ponds (Hero et al. 1998), and/ or unpredictable weather conditions (Prado et al. 2005). The putative low proportion of explosive breeders in Betampona can presumably be explained by weather conditions (e.g., rainfall events) that — apart from cyclones — are less unpredictable in eastern Madagascar, 
where the precipitation regime would enable streams to flow and side pools to be filled for longer periods.

\section{Activity period}

The majority of species showed a preferred period of activity. Yet, a relatively large proportion (46\%) is active year-round. Winter and early spring are the seasons with the highest amphibian activity, which differs from other studies conducted on the eastern belt where species richness was evenly distributed throughout the year (Heinermann et al. 2015), or during the warm-wet season (Strauß et al. 2016). This also contrasts with other studies performed in tropical environments, where most amphibian activity was concentrated in the warm season (e.g., Lopez et al. 2011, Schalk et al. 2016). This suggests that surveys in Betampona could be concentrated during winter and early spring for more cost-effective monitoring.

\section{Environmental drivers}

The activity of a large majority of species (76\%) is driven by climatic and weather conditions. The high importance of temperature on species activity contrasts with Heinermann et al. (2015) data from Analamazaotra forest (central eastern Madagascar). In Analamazaotra rainfall is the best predictor of species richness. The dependence on temperature is presumably related to its impact on prey availability (i.e., invertebrate activity), but also on physiology and metabolic rates and characteristics of breeding sites (e.g., Gómez-Rodríguez et al. 2010). 
When looking at the population level we observed more complex dynamics, with climatic factors driving species' activity patterns in different directions. The most abundant amphibian taxa, which were detected continually throughout the year, did not respond to climatic fluctuations, in accordance with Duellman and Trueb (1994). However, a number of species with continuous activity were still dependent on climatic and weather fluctuations. This suggests that, even if breeding of continuously active species may not be triggered by specific weather conditions, their activity and abundance can still be influenced by meteorology and climatic variation, presumably through effects on larval development (Benard 2015; Thurman and Garcia 2017) or juvenile survival (Bernal-bautista et al. 2017). All species with continuous activity that were affected by temperature were less numerous in warmer conditions (with the exception of Mantidactylus biporus); potentially a response to reducing the risk of desiccation (Shoemaker 1992).

Rainfall was also an important driver of activity in continuously active taxa, probably because high precipitation reduces the risk of desiccation. Higher temperature and precipitation can indirectly affect amphibian populations through degradation of their breeding habitat (e.g., changes in the hydroperiod; Daszak et al. 2005) or facilitation of infectious disease transmission (Carey and Alexander 2003).

The only species with observed sporadic activity (Boophis albilabris) clearly responded to weekly precipitation, likely due to its explosive breeding strategy (Wells 1977; Prado et al. 2005; Heinermann et al. 2015). Despite its peak of activity being in summer, this species was also strongly dependent on low daily humidity and low temperatures. The observation of the dependence on daily humidity is probably the result of the unique detection of the peak of activity of this species during a particularly dry day, five days after a heavy rainfall episode 
that may have induced an explosive breeding event. The activity of this species is probably triggered by rain, but mainly during the coldest days of summer, as previously observed for a closely related species (i.e., B. tsilomaro; Andreone et al. 2002).

\section{Directions for research and conservation}

Species activity varies throughout the year, but varies even more between years. Studies of amphibian activity patterns that are not based on long-term sampling schemes may lead to erroneous or incomplete assumptions, even in seasonal tropical systems.

The high proportion of species with continuous activity and the higher number of species detected during winter and early spring indicate that sampling campaigns may be concentrated during this period for cost-effective monitoring of the community as a whole. Because of the high interannual variability in activity, studies focussed on single species are challenging. Nevertheless, we identified a significant proportion of species that exhibit a higher activity during one season, with a strong dependence on climatic variables. Therefore, studies focusing on single species along the eastern rainforest belt can be concentrated during specific periods for cost-effective surveys. This is also true for species that expressed weak seasonality but were dependent on weather and climate. Targeted surveys can be planned when suitable weather conditions are met.

Climate warming is expected to shift species activity and community composition and structure in the near future (Bellard et al. 2012). We showed that species with continuous activity can still have activity patterns which largely depend on weather conditions, contrary to former assumptions (Duellman and Trueb 1994). This emphasises the need to carefully 
monitor population trends in regard to future climate change, regardless of species seasonality. Given the climatic trends (Bellard et al. 2012) and the important isolation of the Betampona forest, we fear that most amphibian species will be strongly affected. Studies focussing on single species should be prioritised on those most sensitive to temperature and precipitation variation.

The unique amphibian community of Betampona is facing a host of conservation threats. Betampona, like much of Madagascar, suffers from increasing rates of habitat alteration and fragmentation (Vallan 2000; Harper et al. 2007; Allnutt et al. 2008; Ghulam 2014; McConnell et al. 2015; Vieilledent et al. 2018), a trend which is likely to continue in the near future, even in formally protected areas (e.g., Piludu et al. 2015). The positive report of amphibian chytrid fungus on the island (Bletz et al. 2015), the presence (and ongoing expansion) of the invasive Asian toad Duttaphrynus melanostictus (Pearson 2015, McClelland et al. 2015, Licata et al. 2019) and other invasive species such as the day geckoes Phelsuma grandis and P. laticauda (Dubos 2013; Dubos et al. 2014), Hoplobatrachus tigerinus (Goodman et al. 2017) also represent a threat for this imperiled community.

Better targeting and prioritisation of conservation action heavily relies on the detection of putative phenological shifts and population declines, which aligns well with recommendations reported in the action plan for amphibian conservation in Madagascar (Andreone et al. 2016). Understanding the whole picture of species assemblages in Madagascar (and other seasonal tropical systems) represents an important challenge and is still far from being achieved. Making use of technology such as automated sound loggers with the establishment of bioacoustics surveys, enabling reliable identification of cryptic or polytypic species (Vieites et al. 2009; Köhler et al. 2017), may support not only the 
monitoring of populations and communities but also the description of new species (Rosa et al. 2012), and could facilitate continuous, long-term surveys.

The study of temporal patterns of species diversity while accounting for multiple temporal scales will enable the identification of suitable monitoring periods, the assessment of species' sensitivity to climate-change, and setting optimal conditions for captive breeding or translocation for the most endangered species (Andreone and Randriamahazo 2008). Longterm, comparable monitoring in several key forests of Madagascar, as well as in any tropical systems with apparent seasonality, could provide a powerful tool to monitor community and population changes and highlight possible ecological crises in amphibian and other vertebrate communities.

\section{Acknowledgements}

We are thankful to the Madagascar Fauna and Flora Group for allowing us to use the data and to Cel and Honoré Alex, who participated in the data collection. Our thanks also to Juliana Rasoma, MFG, for help verifying the meteorological data. We thank Boris Leroy for his continued help. The field survey was carried out with the collaboration of Departement de Biologie Animale (University of Antananarivo), Parc Botanique et Zoologique de Tsimbazaza (Antananarivo) and the Madagascar Fauna and Flora Group. Finally, we wish to thank A. Bollen, A. Katz, G. Kett and C. Welch for their continuous encouragement and support; the porters in the field, the cooks, our driver and all the people from Rendrirendry for their unconditional help, without whom this project would not have been possible. This research project was partially financially supported by Saint Louis Zoo's Wildcare Institute, Museo Regionale di Scienze Naturali, and Gondwana Conservation and Research. The work of AC is 
supported by the Portuguese National Funds through FCT - Foundation for Science and Technology - under the IF/00209/2014/CP1256/CT0011 Exploratory Research Project and the Investigador FCT (IF) grant (IF/00209/2014).

\section{References}

Allnutt TF, Ferrier S, Manion G, et al (2008) A method for quantifying biodiversity loss and its application to a 50-year record of deforestation across Madagascar. Conserv Lett 1:173-181. doi: 10.1111/j.1755-263X.2008.00027.x

Andreone F (1994) The amphibians of Ranomafana rain forest, Madagascar - preliminary community analysis and conservation considerations. Oryx 28:207-214. doi: 10.1017/ S003060530002857X

Andreone F (1996) Seasonal variations of the amphibian communities in two rainforests of Madagascar. Biogéographie de Madagascar 1996:397-402.

Andreone F, Dawson J, Rabemananjara F, et al (2016) New Sahonagasy Action Plan 2016-2020. Amphibian Specialist Group, Torino

Andreone F, Randriamahazo H (2008) Sahonagasy Action Plan. Conservation Programs for the Amphibians of Madagascar. Museo Regionale di Scienze Naturali, Conservation International, IUCN / Amphibian Specialist Group, Bogotà

Andreone F, Rosa GM, Noël J, et al (2010) Living within fallen palm leaves: The discovery of an unknown Blommersia (Mantellidae: Anura) reveals a new reproductive strategy in the amphibians of Madagascar. Naturwissenschaften 97:525-543. doi: 10.1007/ s00114-010-0667-x 
Andreone F, Vences M, Guarino FM, et al (2002) Natural history and larval morphology of Boophis occidentalis (Anura: Mantellidae: Boophinae) provide new insights into the phylogeny and adaptive radiation of endemic Malagasy frogs. J Zool 257:425-438. doi: $10.1017 / \mathrm{S} 0952836902001036$

Barton K (2018) MuMIn: Multi-Model Inference. R package.

Baselga A (2010) Partitioning the turnover and nestedness components of beta diversity. Glob Ecol Biogeogr 19:134-143. doi: 10.1111/j.1466-8238.2009.00490.x

Baselga A, Bonthoux S, Balent G (2015) Temporal beta biversity of bird assemblages in agricultural landscapes: land cover change vs. stochastic processes. PLoS One 1-14. doi: 10.1371/journal.pone.0127913

Baselga A, Orme DL (2012) betapart: an R package for the study of beta diversity. Methods Ecol Evol 3:808-812. doi: 10.1111/j.2041-210X.2012.00224.x

Bates D, Mächler M, Bolker B, Walker S (2015) Fitting linear mixed-effects models using lme4. J Stat Softw 67:1-51. doi: 10.18637/jss.v067.i01

Bellard C, Bertelsmeier C, Leadley P, et al (2012) Impacts of climate change on the future of biodiversity. Ecol Lett 15:365-377. doi: 10.1111/j.1461-0248.2011.01736.x

Bellati A, Scherz MD, Megson S, et al (2018) Resurrection and re-description of Plethodontohyla laevis (Boettger, 1913) and transfer of Rhombophryne alluaudi (Mocquard, 1901) to the genus Plethodontohyla (Amphibia, Microhylidae, Cophylinae). Zoosystematics Evol 94:109-135. doi: 10.3897/zse.94.14698

Benard MF (2015) Warmer winters reduce frog fecundity and shift breeding phenology, which consequently alters larval development and metamorphic timing. Glob Chang Biol 
Bernal-bautista MH, Turriago-gonzález JL, Villa-navarro FA (2017) Impact of daily variable temperatures in life-history traits of tropical anurans. Rev Biol Trop 65:55-63.

Bertoluci J, Rodrigues MT (2002) Seasonal patterns of breeding activity of Atlantic Rainforest anurans at Boracéia, Southeastern Brazil. Amphibia-Reptilia 23:161-167. doi: $10.1163 / 156853802760061804$

Bevier CR (1997) Breeding activity and chorus tenure of two neotropical hylid frogs. Herpetologica 53:297-311.

Bletz MC, Rosa GM, Andreone F, et al (2015) Widespread presence of the pathogenic fungus Batrachochytrium dendrobatidis in wild amphibian communities in Madagascar. Sci Rep 5:1-10. doi: 10.1038/srep08633

Brown JL, Sillero N, Glaw F, et al (2016) Spatial biodiversity patterns of madagascar's amphibians and reptiles. PLoS One 11:1-26. doi: 10.1371/journal.pone.0144076

Burnham KP, Anderson DR (2002) Model selection and multimodel inference: a practical information-theoretic approach, Springer S. New York

Canale C, Henry P (2010) Adaptive phenotypic plasticity and resilience of vertebrates to increasing climatic unpredictability. Clim Res 43:135-147. doi: 10.3354/cr00897

Carey C, Alexander MA (2003) Climate change and amphibian declines: Is there a link? Divers Distrib 9:111-121. doi: 10.1046/j.1472-4642.2003.00011.x

Crump M (1974) Reproductive strategies in a tropical anuran community. Misc Publ Kansas Univ 61:1-68. doi: 10.1007/s13398-014-0173-7.2 
Daszak P, Scott DE, Kilpatrick AM, et al (2005) Amphibian population declines at Savannah River Site are linked to climate, not chytridiomycosis. Ecology 86:3232-3237.

dos Santos TG, Vasconcelos T da S, Rossa-Feres D de C, Haddad CFB (2009) Anurans of a seasonally dry tropical forest: Morro do Diabo State Park, São Paulo state, Brazil. J Nat Hist 43:973-993. doi: 10.1080/00222930802702498

Dubos N (2013) New locality record for Phelsuma grandis (Sauria: Gekkonidae) in Reunion, in sympatry with the Critically Endangered Phelsuma inexpectata. Herpetol Notes 6:309-311.

Dubos N, Piludu N, Andriantsimanarilafy RR, et al (2014) New findings of Phelsuma grandis and P. laticauda (Sauria: Gekkonidae) at the southern edge of the range of the endangered Phelsuma serraticauda in eastern Madagascar. Herpetol Notes 7:21-23.

Duellman WE (1995) Temporal fluctuations in abundances of anuran amphibians in a seasonal Amazonian rainforest. J Herpetol 29:13-21.

Duellman WE, Trueb L (1994) Biology of Amphibians. The Johns Hopkins University Press, London

Frederiksen M, Daunt F, Harris MP, Wanless S (2008) The demographic impact of extreme events: stochastic weather drives survival and population dynamics in a long-lived seabird. J Anim Ecol 78:1020-1029. doi: 10.1111/j.1365-2656.2007.0

Ganzhorn JU, Lowry PP, Schatz GE, Sommer S (2001) The biodiversity of Madagascar: One of the world's hottest hotspots on its way out. Oryx 35:346-348. doi: 10.1046/j. 1365-3008.2001.00201.x

Ganzhorn JU, Wilmé L, Mercier J (2014) Explaining Madagascar's biodiversity. In: Scales I 
(ed) Conserv. Environ. Manag. Madagascar. Taylor \& Francis Group, pp 17-43

Gardner T, Fitzherbert E, Drewes R, Howell K (2007) Spatial and temporal patterns of abundance and diversity of an East African leaf litter amphibian fauna. Biotropica 39:105-113.

Ghulam A (2014) Monitoring tropical forest degradation in Betampona Nature Reserve, Madagascar using multisource remote sensing data fusion. IEEE J Sel Top Appl Earth Obs Remote Sens 7:4960-4971. doi: 10.1109/JSTARS.2014.2319314

Glaw F, Vences M (2007) A field guide to the amphibians and reptiles of Madagascar. Third edition, Vences \& Glaw Verlags. Köln

Glaw F, Vences M (1996) Bemerkungen zur fortpflanzung des waldskinks Amphiglossus melanopleura aus Madagaskar (Sauria: Scincidae), mit einer übersicht über die fortpflanzungsperioden madagassischer reptilien. Salamandra 32:211-216.

Glos J (2003) The amphibian fauna of the Kirindy dry forest in western Madagascar. Salamandra 39:75-90.

Gómez-Rodríguez C, Díaz-Paniagua C, Bustamante J, et al (2010) Inter-annual variability in amphibian assemblages: Implications for diversity assessment and conservation. Aquat Conserv Mar Freshw Ecosyst 20:668-677. doi: 10.1002/aqc.1134

Goodman SM, Benstead JP (2005) Updated estimates of biotic diversity and endemism for Madagascar. Oryx 39:73-77. doi: 10.1017/S0030605305000128

Goodman SM, Raselimanana AP, Andriniaina HA, et al (2017) The distribution and ecology of invasive alien vertebrate species in the greater Toamasina region, central eastern Madagascar. Malagasy Nat 12:95-109. 
Gottsberger B, Gruber E (2004) Temporal partitioning of reproductive activity in a neotropical anuran community. J Trop Ecol 20:271-280. doi: 10.1017/ S0266467403001172

Grant RA, Chadwick EA, Halliday T (2009) The lunar cycle: a cue for amphibian reproductive phenology? Anim Behav 78:349-357. doi: 10.1016/j.anbehav.2009.05.007

Green GM, Sussman RW (1990) Deforestation history of the eastern rain forests of Madagascar from satellite images. Science (80- ) 248:212-215. doi: 10.1126/science. 248.4952 .212

Gross J (2019) AmphibiaWeb. https://amphibiaweb.org/. Accessed 15 Feb 2019

Grueber CE, Nakagawa S, Laws RJ, Jamieson IG (2011) Multimodel inference in ecology and evolution: Challenges and solutions. J Evol Biol 24:699-711. doi: 10.1111/j. $1420-9101.2010 .02210 . x$

Harper GJ, Steininger MK, Tucker CJ, et al (2007) Fifty years of deforestation and forest fragmentation in Madagascar. Environ Conserv 34:325-333. doi: 10.1017/ S0376892907004262

Heinermann J, Rodríguez A, Segev O, et al (2015) Year-round activity patterns in a hyperdiverse community of rainforest amphibians in Madagascar. J Nat Hist 49:22132231. doi: $10.1080 / 00222933.2015 .1009513$

Hero J-M, Gascon C, Magnusson WE (1998) Direct and indirect effects of predation on tadpole community structure in the Amazon rainforest. Austral Ecol 23:474-482. doi: 10.1111/j.1442-9993.1998.tb00755.x

Ho C-H, Kim J-H, Jeong J-H, et al (2006) Variation of tropical cyclone activity in the South 
Indian Ocean: El Niño-Southern Oscillation and Madden-Julian Oscillation effects. J

Geophys Res 111:D22101. doi: 10.1029/2006JD007289

Johnson JB, Omland KS (2004) Model selection in ecology and evolution. Trends Ecol Evol 19:101-108. doi: 10.1016/j.tree.2003.10.013

Köhler J, Jansen M, Rodríguez A, et al (2017) The use of bioacoustics in anuran taxonomy: theory, terminology, methods and recommendations for best practice. Zootaxa 4251:1124.

Kupfer A, Nabhitabhata J, Himstedt W (2005) Life history of amphibians in the seasonal tropics: Habitat, community and population ecology of a caecilian (genus Ichthyophis). J Zool 266:237-247. doi: 10.1017/S0952836905006849

Leprieur F, Oikonomou A (2013) The need for richness- independent measures of turnover when delineating biogeographical regions. J Biogeogr 41:417-420. doi: 10.1111/jbi. 12258

Licata F, Ficetola GF, Freeman K, et al (2019) Abundance, distribution and spread of the invasive Asian toad Duttaphrynus melanostictus in eastern Madagascar. Biol Invasions 21:1615-1626. doi: DOI: 10.1007/s10530-019-01920-2

Lopez JA, Scarabotti PA, Ghirardi R (2011) Seasonal patterns of abundance and recruitment in an amphibian assemblage from the Parana River floodplain. Interciencia 36:538-544.

Marques O, Eterovic A, Endo W (2001) Seasonal activity of snakes in the Atlantic forest in southeastern Brazil. Amphibia-Reptilia 22:103-111. doi: 10.1163/156853801750096213

McClelland P, Reardon JT, Kraus F, et al (2015) Toad eradication feasibility report for Madagascar. Te Anau, New Zealand 
McConnell W, Viña A, Kull C, Batko C (2015) Forest transition in Madagascar's highlands: initial evidence and implications. Land 4:1155-1181. doi: 10.3390/land4041155

Moussus J, Jiguet F, Clavel J, Julliard R (2009) A method to estimate phenological variation using data from large scale abundance monitoring programmes. Bird Study 56:198-212. doi: $10.1080 / 00063650902792064$

Oksanen AJ, Blanchet FG, Kindt R, et al (2015) Community Ecology Package ‘vegan'. R version 2.3-1. Available: https://cran.r-project.org/web/packages/vegan/.

Pearson RG (2015) Asian common toads in Madagascar: An urgent effort to inform surveys and eradication efforts. Glob Chang Biol 21:9. doi: 10.1111/gcb.12693

Peel MC, Finlayson BL, McMahon TA (2007) Updated world map of the Köppen-Geiger climate classification. Hydrol Earth Syst Sci Discuss 4:439-473. doi: $10.1127 / 0941-2948 / 2006 / 0130$

Piludu N, Dubos N, Razafimanahaka JH, et al (2015) Distribution, threats and conservation of a Critically Endangered amphibian (Mantella aurantiaca) in eastern Madagascar. Herpetol Notes 8:119-123.

Prado C, Uetanabaro M, Haddad C (2005) Breeding activity patterns, reproductive modes, and habitat use by anurans (Amphibia) in a seasonal environment in the Pantanal, Brazil. Amphibia-Reptilia 26:211-221. doi: 10.1163/1568538054253375

R Core Team (2018) R: A language and environment for statistical computing. R Foundation for Statistical Computing.

Rasambainarivo F, Farris ZJ, Andrianalizah H, Parker P G (2017). Interactions Between Carnivores in Madagascar and the Risk of Disease Transmission. EcoHealth 14: 691- 
703.

Riemann JC, Ndriantsoa SH, Rödel MO, Glos J (2017) Functional diversity in a fragmented landscape - Habitat alterations affect functional trait composition of frog assemblages in Madagascar. Glob Ecol Conserv 10:173-183. doi: 10.1016/j.gecco.2017.03.005

Rosa GM, Andreone F, Crottini A, et al (2012) The amphibians of the relict Betampona lowelevation rainforest, eastern Madagascar: An application of the integrative taxonomy approach to biodiversity assessments. Biodivers Conserv 21:1531-1559. doi: 10.1007/ s10531-012-0262-X

Rosa GM, Crottini A, Noël J, et al (2014) A new phytotelmic species of Platypelis (Microhylidae: Cophylinae) from the Betampona Reserve, eastern Madagascar. Salamandra 50:201-214.

Rosa GM, Noël J, Andreone F (2011) Confirming a new population of the endangered Paroedura masobe (Squamata: Gekkonidae) in the relict Betampona low elevation rainforest, eastern Madagascar. Herpetol Notes 4:405-407.

Saenz D, Fitzgerald LA, Baum KA (2006) Abiotic correlates of anuran calling phenology: the importance of rain, temperature, and season. Herpetol Monogr 20:64. doi: 10.1655/0733-1347(2007)20[64:ACOACP $] 2.0 . C O ; 2$

Schalk CM, Saenz D (2016) Environmental drivers of anuran calling phenology in a seasonal Neotropical ecosystem. Austral Ecol 41:16-27. doi: 10.1111/aec.12281

Segev O, Andreone F, Pala R, et al (2012) Reproductive phenology of the Dyscophus antongili, in an urban pond of Madagascar's east coast. Acta Herp 7(2) 7:331-340.

Shoemaker VH (1992) Exchange of water, ions, and respiratory gases in terrestrial 
amphibians. In: Feder ME, Burggren WW (eds) Environ. Physiol. Amphib., University. pp $125-150$

Socolar JB, Gilroy JJ, Kunin WE, Edwards DP (2016) How should beta-diversity inform biodiversity conservation? Trends Ecol Evol 31:67-80. doi: 10.1016/j.tree.2015.11.005

Sparks T, Carey P (1995) The responses of species to climate over two centuries : an analysis of the Marsham phenological record, 1736-1947. J Ecol 83:321-329.

Strauß A, Guilhaumon F, Randrianiaina RD, et al (2016) Opposing patterns of seasonal change in functional and phylogenetic diversity of tadpole assemblages. PLoS One 11:e0151744. doi: 10.1371/journal.pone.0151744

Thurman LL, Garcia TS (2017) Differential plasticity in response to simulated climate warming in a high-elevation amphibian assemblage. J Herpetol 51:232-239. doi: $10.1670 / 16-502$

Tökölyi J, McNamara JM, Houston AI, Barta Z (2012) Timing of avian reproduction in unpredictable environments. Evol Ecol 26:25-42. doi: 10.1007/s10682-011-9496-4

Tonkin JD, Bogan MT, Bonada N, et al (2017) Seasonality and predictability shape temporal species diversity. Ecology 98:1201-1216. doi: 10.1002/ecy.1761

Vallan D (2000) Influence of forest fragmentation on amphibian diversity in the nature reserve of Ambohitantely, highland Madagascar. Biol Conserv 96:31-43. doi: 10.1016/ S0006-3207(00)00041-0

van de Pol M, Cockburn A (2011) Identifying the critical climatic time window that affects trait expression. Am Nat 177:698-707. doi: 10.1086/659101 
Vasconcelos T da S, dos Santos TG, Rossa-Feres D de C, Haddad CFB (2011) Spatial and temporal distribution of tadpole assemblages (Amphibia, Anura) in a seasonal dry tropical forest of southeastern Brazil. Hydrobiologia 673:93-104. doi: 10.1007/ s 10750-011-0762-9

Vieilledent G, Grinand C, Rakotomalala FA, et al (2018) Combining global tree cover loss data with historical national forest cover maps to look at six decades of deforestation and forest fragmentation in Madagascar. Biol Conserv 222:189-197. doi: 10.1016/j.biocon. 2018.04.008

Vieites DR, Wollenberg KC, Andreone F, et al (2009) Vast underestimation of Madagascar's biodiversity evidenced by an integrative amphibian inventory. Proc Natl Acad Sci U S A 106:8267-72. doi: 10.1073/pnas.0810821106

Vignoli L, D'Amen M, Della Rocca F, et al (2014) Contrasted influences of moon phases on the reproduction and movement patterns of four amphibian species inhabiting different habitats in central Italy. Amphibia-Reptilia 35:247-254.

Visser ME, Both C (2005) Shifts in phenology due to global climate change: the need for a yardstick. Proc Biol Sci 272:2561-2569. doi: 10.1098/rspb.2005.3356

Wells KD (2010) The ecology and behavior of amphibians. University of Chicago Press, Chicago and London

Wells KD (1977) The social behaviour of anuran amphibians. Anim Behav 25:666-693. doi: $10.1016 / 0003-3472(77) 90118-X$

Whiteman HH, Wissinger SA (2005) Amphibian population cycles and long-term data sets. Amphib. Declines Conserv. Status United States Species. pp 177-184 


\section{Data Accessibility Statement}

The data used in this study is available online as an R object in the supporting information. 
Figures legends

Fig. 1 Temporal variation in the six selected weather variables, recorded at Betampona, Madagascar, between 2009 and 2017. Within-year variation is represented along the $\mathrm{x}$ axe while between-year variation is represented by the colour gradient. Dark-blue points represent the oldest records (2009) while light-blue points represent the most recent ones (2017). Boxplots represent $25 \%$ and $75 \%$ quartiles, bars represent the median (per month for daily variables; per week for weekly variables)

Fig. 2 Patterns of temporal beta diversity of amphibian communities at Betampona. First, we illustrate hypothetical patterns of changes in community composition according to temporal variation, including seasonal and between-years variability (a); circles symbolised the communities (i.e. all species recorded in one transect at one site and for one date), which are coloured according to the season they were sampled. Under these assumptions, we expect that if changes in community composition are strongly correlated with seasonal variability, we should observe a repeated distribution of communities between years, i.e. season by season. On the opposite, if changes in community composition are independent from seasonal variability, we should not detect any structured patterns within years. To specifically study how species composition changes through time, we show the ordinations (MDS) assessed for each transects (i.e. on the ridge top (b) and both based on Jaccard (for presence-absence data) and Bray-Curtis dissimilarities (for abundance data), within the slope (c) and along the edge of the forest stream (d) for the two studied sites). This spatial and topographical separations allow to focus our investigations strictly on temporal changes; the lines connect all the communities sampled a given year, at a single transect, therefore representing the temporal trajectories of community composition across years 
Fig. 3 Within-year (a), and between-year (b) variation in abundances of 47 amphibian taxa from Betampona Strict Nature Reserve, eastern Madagascar. Abundances are expressed as (a) the proportion of total abundances at a given date and (b) the mean number of individuals counted per day of observation. The more abundant the higher the curve (a) and the larger the circle (b). We excluded species with less than three individuals recorded $(n=4)$ 

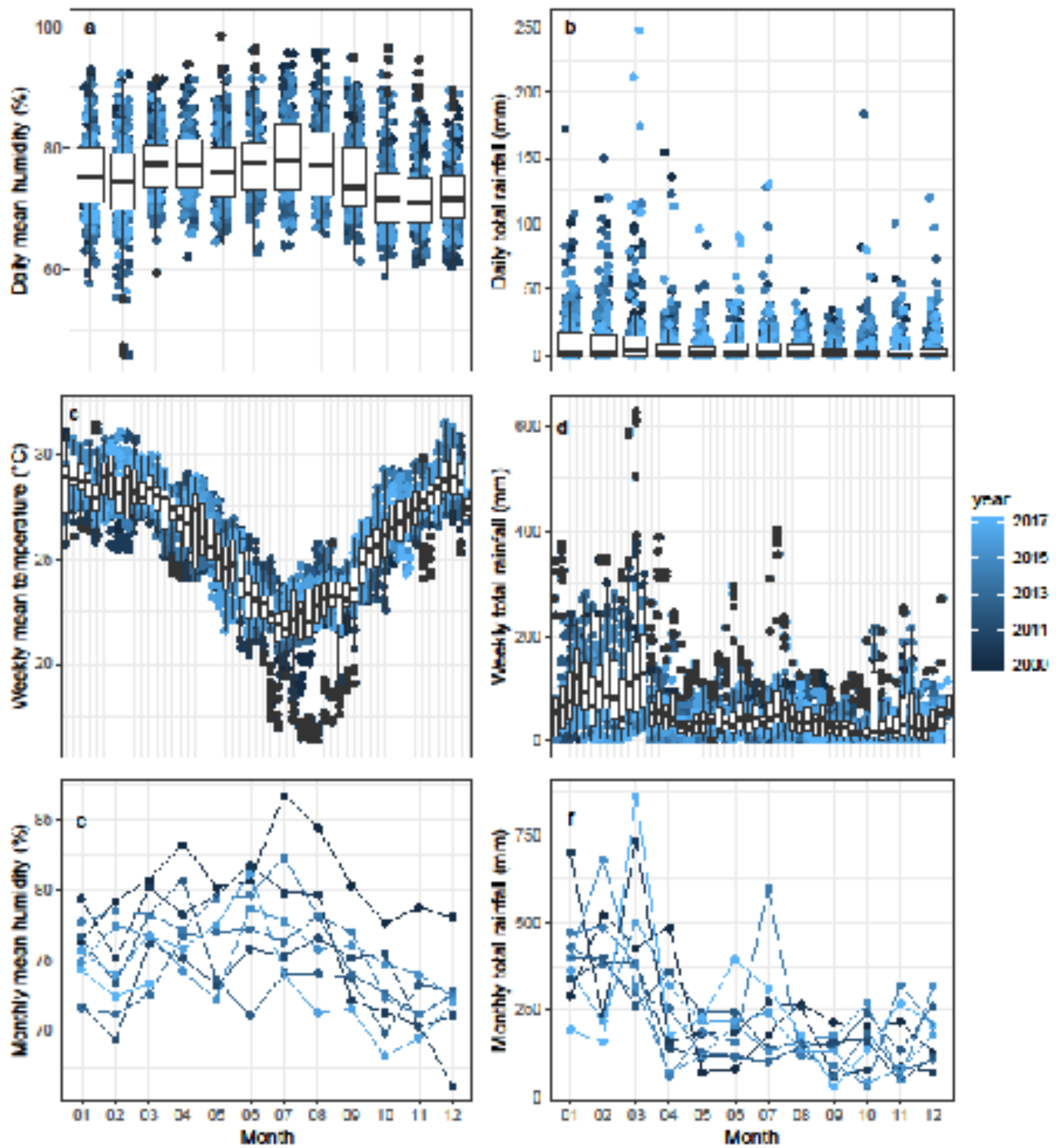

Figure 1 
(a) Hypothetical patterns
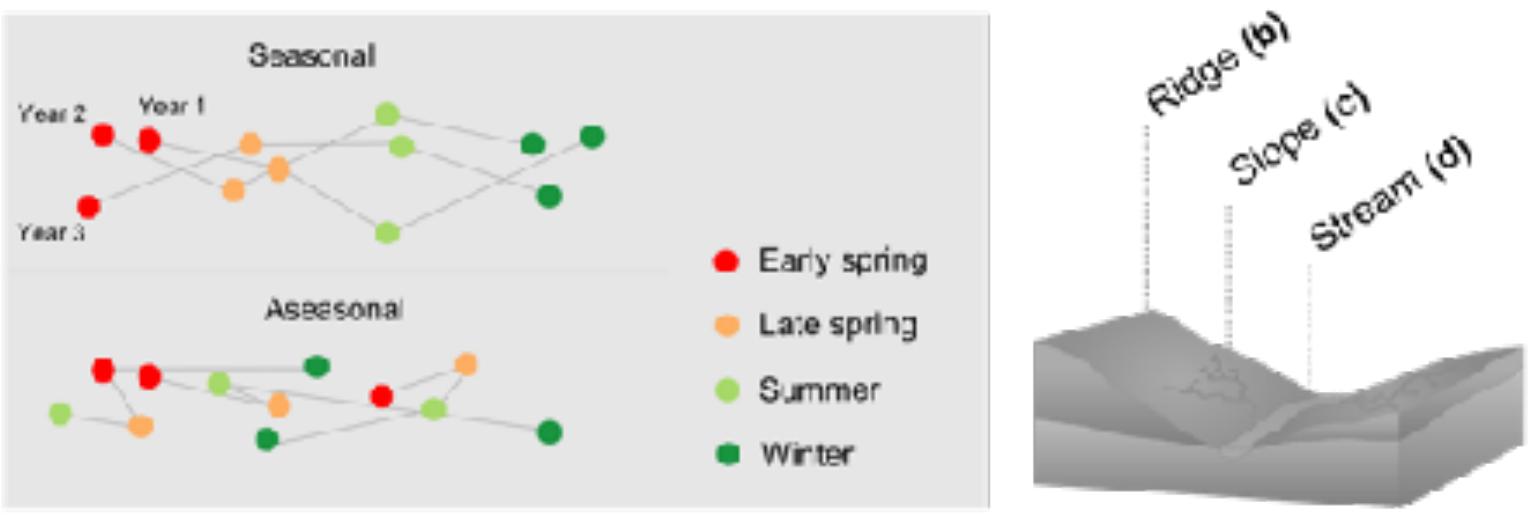

\section{Sahambendrana}
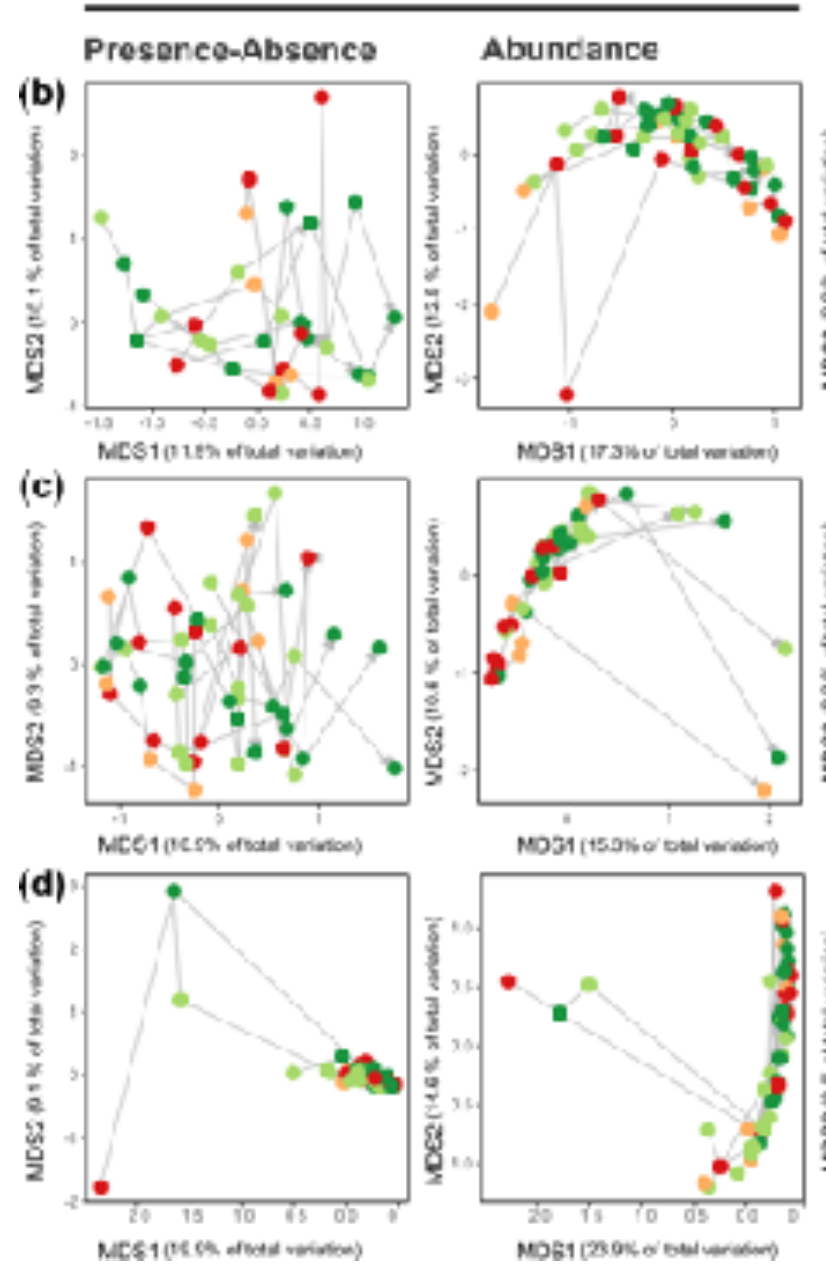

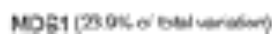

Sahabcfoza

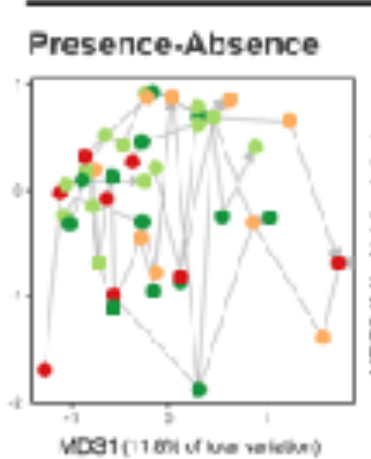

Abundance
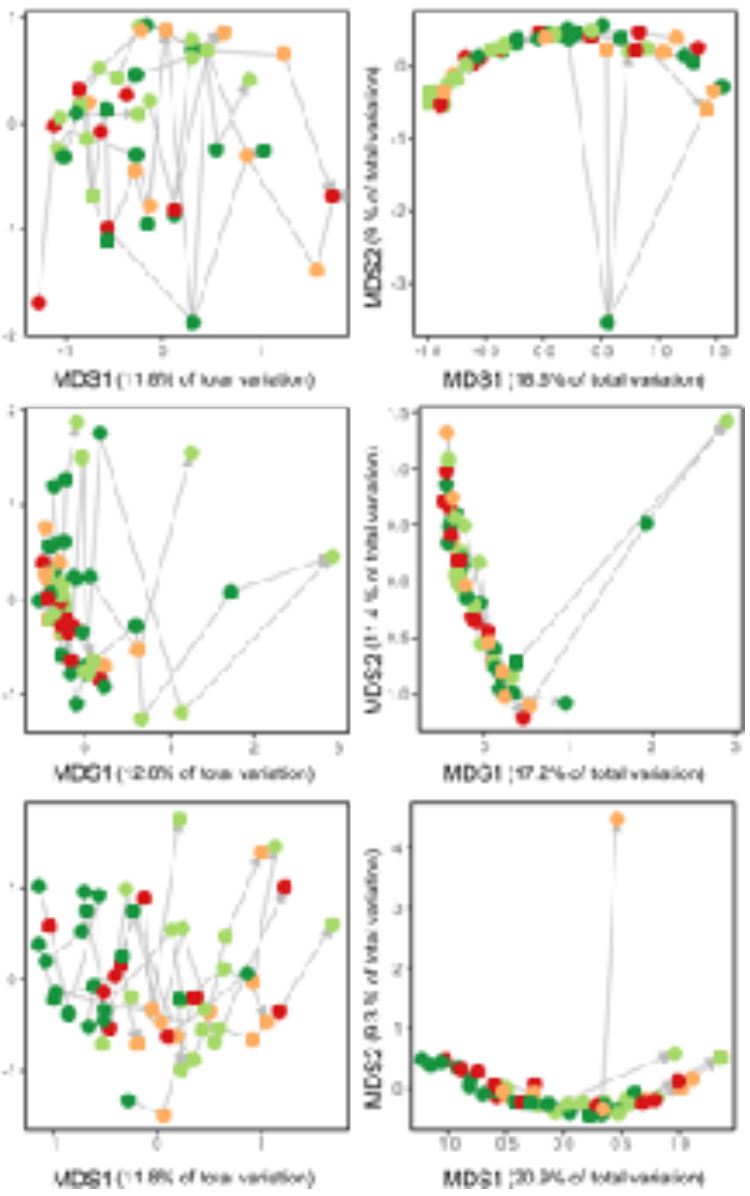

Figure 2 


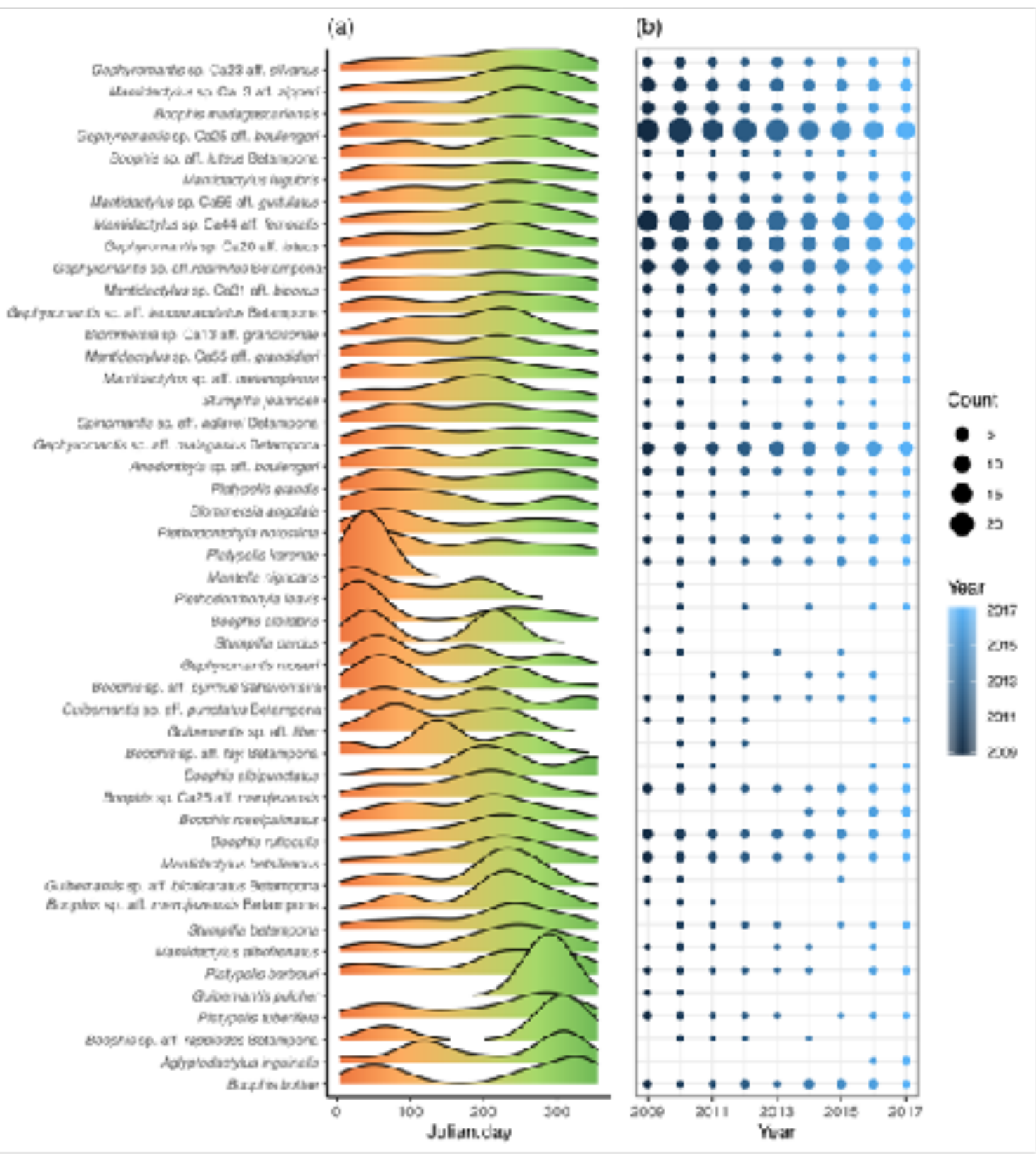

Figure 3 
Table 1. Results of PERMANOVAs (999 permutations) testing the marginal effects (i.e. individual contribution of each variable in the overall model) of seasons and years in each of the 6 transects for both community composition (Jaccard dissimilarity) and abundance (BrayCurtis dissimilarity).

Jaccard dissimilarity

$\begin{array}{llllllll}\text { df } & R^{2} & F & P & d f & R^{2} & F & P\end{array}$

Sahabendrana

\begin{tabular}{lllll}
\hline Ridge & & & & \\
\hline Season & 3 & 0.05 & 1.02 & 0.44 \\
Year & 8 & 0.17 & 1.25 & $0.07\left(^{*}\right)$ \\
Residual & 48 & 0.72 & & \\
Slope & & & & \\
\hline Season & 3 & 0.04 & 0.69 & 0.81 \\
Year & 8 & 0.16 & 1.12 & 0.28 \\
Residual & 43 & 0.79 & & \\
Stream & & & & \\
\hline Season & 3 & 0.05 & 1.12 & 0.29 \\
Year & 8 & 0.20 & 1.66 & $0.007^{* *}$ \\
Residual & 48 & 0.72 & & \\
\hline
\end{tabular}

\section{Sahabefoza}

\begin{tabular}{|c|c|c|c|c|}
\hline Ridge & & & & \\
\hline & 3 & 0.05 & 1.01 & 0.44 \\
\hline & 8 & 0.17 & 1.28 & $0.09(*)$ \\
\hline & 49 & 0.78 & & \\
\hline \multicolumn{5}{|l|}{ Slope } \\
\hline & 3 & 0.05 & 1.03 & 0.44 \\
\hline & 8 & 0.18 & 1.39 & $0.02 *$ \\
\hline & 47 & 0.78 & & \\
\hline \multicolumn{5}{|l|}{ Stream } \\
\hline & 3 & 0.13 & 3.07 & $0.001 * * *$ \\
\hline & 8 & 0.21 & 1.83 & $0.001 * * *$ \\
\hline & 46 & 0.65 & & \\
\hline
\end{tabular}

Bray-Curtis dissimilatity

\begin{tabular}{|c|c|c|c|c|c|c|c|c|c|}
\hline Ridge & & & & & Ridge & & & & \\
\hline Season & 3 & 0.07 & 1.45 & 0.1 & & 3 & 0.10 & 2.12 & $0.02 *$ \\
\hline Year & 8 & 0.25 & 2.06 & $0.003 * *$ & & 8 & 0.20 & 1.67 & $0.02 *$ \\
\hline Residual & 43 & 0.65 & & & & 47 & 0.71 & & \\
\hline Slope & & & & & Slope & & & & \\
\hline Season & 3 & 0.07 & 1.48 & $0.08\left(^{*}\right)$ & & 3 & 0.04 & 0.88 & 0.61 \\
\hline Year & 8 & 0.19 & 1.48 & $0.03 *$ & & 8 & 0.17 & 1.34 & $0.07\left(^{*}\right)$ \\
\hline Residual & 45 & 0.71 & & & & 49 & 0.78 & & \\
\hline
\end{tabular}




\begin{tabular}{|c|c|c|c|c|c|c|c|c|c|}
\hline \multicolumn{5}{|l|}{ Stream } & \multicolumn{5}{|l|}{ Stream } \\
\hline Season & 3 & 0.07 & 1.7 & $0.07(*)$ & & 3 & 0.13 & 3.34 & $0.001 * * *$ \\
\hline Year & 8 & 0.18 & 1.6 & $0.03 *$ & & 8 & 0.27 & 2.65 & $0.001 * * *$ \\
\hline Residual & 48 & 0.70 & & & & 46 & 0.58 & & \\
\hline
\end{tabular}

$(*) p<0.1 ; * p<0.05 ; * * p<0.01 ; * * * p<0.001$

Table 2. Results of distance-based RDAs testing the influence of climatic variables into variation of community composition (Jaccard dissimilarity) and abundance (Bray-Curtis dissimilarity); type II tests.

\begin{tabular}{|c|c|c|c|c|}
\hline \multirow[b]{2}{*}{ Proportion of variation } & \multicolumn{2}{|c|}{ Jaccard } & \multicolumn{2}{|c|}{ Bray-Curtis } \\
\hline & $\mathrm{R}^{2}$ & & $\mathrm{R}^{2}$ & \\
\hline Conditional variation $($ Site + transect $)$ & 0.24 & & 0.166 & \\
\hline Constrained variation (Climatic variables) & 0.017 & & 0.018 & \\
\hline Unconstrained variation & 0.743 & & 0.816 & \\
\hline Climatic variables & $\mathrm{F}$ & $P$ & $\mathrm{~F}$ & $P$ \\
\hline Daily humidity & 1.11 & 0.202 & 1.07 & 0.121 \\
\hline Monthly humidity & 1.22 & $0.061(*)$ & 10.07 & 0.141 \\
\hline Daily rain & 0.93 & 0.642 & 0.97 & 0.617 \\
\hline Weekly rain & 0.91 & 0.725 & 0.96 & 0.696 \\
\hline Monthly rain & 1.21 & $0.076(*)$ & 1.01 & 0.433 \\
\hline Weekly temperature & 1.33 & $0.018^{*}$ & 1.51 & $0.001 * * *$ \\
\hline
\end{tabular}

$(*) p<0.1 ; * p<0.05 ; * * p<0.01 ; * * * p<0.001$ 


\section{Supporting information}

Appendix 1. Taxa included in the study that are constituted of two or more genetic lineages morphologically and ecologically very similar.

Mantidactylus sp. Ca44 aff. femoralis, Mantidactylus sp. Ca38 aff. femoralis and Mantidactylus sp. aff. femolugubris; Gephyromantis sp. aff. malagasius "Betampona1" and Gephyromantis sp. aff. malagasius "Betampona2"; Mantidactylus sp. Ca31 aff. biporus and Mantidactylus sp. Ca76 aff. biporus; Mantidactylus betsileanus, Mantidactylus sp. Ca06 aff. tricinctus and Mantidactylus sp. Ca36 aff. betsileanus; Spinomantis sp. Ca09 aff. aglavei and Spinomantis sp. aff. aglavei Betampona; Boophis sp. Ca25 aff. marojezensis and Boophis sp. aff. marojezensis Betampona; Anodonthyla sp. aff. boulengeri lineage AIV and Anodonthyla sp. aff. boulengeri lineage AV; Platypelis grandis and Platypelis sp. aff. grandis; Platypelis barbouri and Platypelis sp. Ca05 "ranjomena"; Mantidactylus albofrenatus and Mantidactylus sp. Ca10 aff. albofrenatus; Guibemantis sp. aff. bicalcaratus Betampona and Guibemantis methueni; Platypelis sp. Ca01 aff. cowani and Platypelis sp. Ca09 aff. cowani "Betampona". 
Table S1. Correlation table of the tested climatic variables (Pearson coefficient). Table a shows the correlations for the whole meteorological data. Table b shows only the selected variables with the data included in the models.

\begin{tabular}{|c|c|c|c|c|c|c|c|c|c|c|c|c|c|c|c|}
\hline $\mathrm{a}$ & $\begin{array}{l}\text { Daily } \\
\text { maxi } \\
\text { mum } \\
\text { tempe } \\
\text { rature }\end{array}$ & $\begin{array}{l}\text { Daily } \\
\text { minimu } \\
\mathrm{m} \\
\text { temperat } \\
\text { ure }\end{array}$ & $\begin{array}{l}\mathrm{Da} \\
\text { ily } \\
\text { rai } \\
\mathrm{n}\end{array}$ & $\begin{array}{l}\text { Dail } \\
\text { y } \\
\text { maxi } \\
\text { mu } \\
\mathrm{m} \\
\text { hum } \\
\text { idity }\end{array}$ & $\begin{array}{l}\text { Dail } \\
\text { y } \\
\text { mini } \\
\mathrm{mu} \\
\mathrm{m} \\
\text { hum } \\
\text { idity }\end{array}$ & $\begin{array}{l}\text { Daily } \\
\text { tempe } \\
\text { rature } \\
\text { range }\end{array}$ & $\begin{array}{l}\text { Daily } \\
\text { mean } \\
\text { tempe } \\
\text { rature }\end{array}$ & $\begin{array}{l}\text { Dail } \\
\text { y } \\
\text { hu } \\
\text { mid } \\
\text { ity } \\
\text { ran } \\
\text { ge }\end{array}$ & $\begin{array}{l}\text { Dail } \\
\text { y } \\
\text { mea } \\
\mathrm{n} \\
\text { hu } \\
\text { mid } \\
\text { ity }\end{array}$ & $\begin{array}{l}\text { Mont } \\
\text { hly } \\
\text { mean } \\
\text { tempe } \\
\text { rature }\end{array}$ & $\begin{array}{l}\text { Mo } \\
\text { nthl } \\
y \\
\text { rain }\end{array}$ & $\begin{array}{l}\text { Mo } \\
\text { nthl } \\
\text { y } \\
\text { mea } \\
\text { n } \\
\text { hu } \\
\text { mid } \\
\text { ity }\end{array}$ & $\begin{array}{l}\text { Week } \\
\text { ly } \\
\text { mean } \\
\text { tempe } \\
\text { rature }\end{array}$ & $\begin{array}{l}\text { We } \\
\text { ekl } \\
\text { y } \\
\text { rai } \\
\text { n }\end{array}$ & $\begin{array}{l}\text { Wee } \\
\text { kly } \\
\text { mea } \\
\text { n } \\
\text { hu } \\
\text { mid } \\
\text { ity }\end{array}$ \\
\hline $\begin{array}{l}\text { Daily maximum } \\
\text { temperature }\end{array}$ & 1.00 & 0.68 & $\begin{array}{l}-0 . \\
10\end{array}$ & $\begin{array}{l}-0.2 \\
9\end{array}$ & $\begin{array}{l}-0.5 \\
1\end{array}$ & 0.87 & 0.96 & 0.45 & $\begin{array}{l}-0.5 \\
3\end{array}$ & 0.78 & $\begin{array}{l}0.1 \\
4\end{array}$ & $\begin{array}{l}-0.4 \\
2\end{array}$ & 0.85 & $\begin{array}{l}-0 . \\
03\end{array}$ & $\begin{array}{l}-0.4 \\
6\end{array}$ \\
\hline $\begin{array}{l}\text { Daily.minimum } \\
\text { temperature }\end{array}$ & 0.68 & 1.00 & $\begin{array}{l}0.1 \\
0\end{array}$ & $\begin{array}{l}-0.2 \\
4\end{array}$ & $\begin{array}{l}-0.2 \\
0\end{array}$ & 0.23 & 0.85 & 0.14 & $\begin{array}{l}-0.2 \\
4\end{array}$ & 0.81 & $\begin{array}{l}0.3 \\
4\end{array}$ & $\begin{array}{l}-0.3 \\
5\end{array}$ & 0.83 & $\begin{array}{l}0.2 \\
0\end{array}$ & $\begin{array}{l}-0.3 \\
0\end{array}$ \\
\hline Daily rain & -0.10 & 0.10 & $\begin{array}{l}1.0 \\
0\end{array}$ & 0.14 & 0.32 & -0.20 & -0.04 & $\begin{array}{l}-0.2 \\
9\end{array}$ & 0.32 & 0.08 & $\begin{array}{l}0.3 \\
1\end{array}$ & 0.11 & 0.03 & $\begin{array}{l}0.5 \\
2\end{array}$ & 0.23 \\
\hline $\begin{array}{l}\text { Daily maximum } \\
\text { humidity }\end{array}$ & -0.29 & -0.24 & $\begin{array}{l}0.1 \\
4\end{array}$ & 1.00 & 0.31 & -0.23 & -0.30 & $\begin{array}{l}-0.0 \\
5\end{array}$ & 0.52 & -0.28 & $\begin{array}{l}0.1 \\
0\end{array}$ & 0.52 & -0.30 & $\begin{array}{l}0.0 \\
9\end{array}$ & 0.54 \\
\hline $\begin{array}{l}\text { Daily minimum } \\
\text { humidity }\end{array}$ & -0.51 & -0.20 & $\begin{array}{l}0.3 \\
2\end{array}$ & 0.31 & 1.00 & -0.54 & -0.44 & $\begin{array}{l}-0.9 \\
7\end{array}$ & 0.97 & -0.24 & $\begin{array}{l}0.1 \\
6\end{array}$ & 0.48 & -0.31 & $\begin{array}{l}0.2 \\
8\end{array}$ & 0.65 \\
\hline $\begin{array}{l}\text { Daily } \\
\text { temperature } \\
\text { range }\end{array}$ & 0.87 & 0.23 & $\begin{array}{l}-0 . \\
20\end{array}$ & $\begin{array}{l}-0.2 \\
3\end{array}$ & $\begin{array}{l}-0.5 \\
4\end{array}$ & 1.00 & 0.71 & 0.51 & $\begin{array}{l}-0.5 \\
4\end{array}$ & 0.49 & $\begin{array}{l}-0.0 \\
5\end{array}$ & $\begin{array}{l}-0.3 \\
3\end{array}$ & 0.56 & $\begin{array}{l}-0 . \\
17\end{array}$ & $\begin{array}{l}-0.4 \\
1\end{array}$ \\
\hline $\begin{array}{l}\text { Daily mean } \\
\text { temperature }\end{array}$ & 0.96 & 0.85 & $\begin{array}{l}-0 \\
04\end{array}$ & $\begin{array}{l}-0.3 \\
0\end{array}$ & $\begin{array}{l}-0.4 \\
4\end{array}$ & 0.71 & 1.00 & 0.38 & $\begin{array}{l}-0.4 \\
6\end{array}$ & 0.85 & $\begin{array}{l}0.2 \\
2\end{array}$ & $\begin{array}{l}-0.4 \\
3\end{array}$ & 0.91 & $\begin{array}{l}0.0 \\
6\end{array}$ & $\begin{array}{l}-0.4 \\
4\end{array}$ \\
\hline $\begin{array}{l}\text { Daily humidity } \\
\text { range }\end{array}$ & 0.45 & 0.14 & $\begin{array}{l}-0 \\
29\end{array}$ & $\begin{array}{l}-0.0 \\
5\end{array}$ & $\begin{array}{l}-0.9 \\
7\end{array}$ & 0.51 & 0.38 & 1.00 & $\begin{array}{l}-0.8 \\
8\end{array}$ & 0.17 & $\begin{array}{l}-0.1 \\
4\end{array}$ & $\begin{array}{l}-0.3 \\
7\end{array}$ & 0.24 & $\begin{array}{l}-0 . \\
27\end{array}$ & $\begin{array}{l}-0.5 \\
4\end{array}$ \\
\hline $\begin{array}{l}\text { Daily mean } \\
\text { humidity }\end{array}$ & -0.53 & -0.24 & $\begin{array}{l}0.3 \\
2\end{array}$ & 0.52 & 0.97 & -0.54 & -0.46 & $\begin{array}{l}-0.8 \\
8\end{array}$ & 1.00 & -0.28 & $\begin{array}{l}0.1 \\
7\end{array}$ & 0.56 & -0.35 & $\begin{array}{l}0.2 \\
7\end{array}$ & 0.72 \\
\hline $\begin{array}{l}\text { Monthly mean } \\
\text { temperature }\end{array}$ & 0.78 & 0.81 & $\begin{array}{l}0.0 \\
8\end{array}$ & $\begin{array}{l}-0.2 \\
8\end{array}$ & $\begin{array}{l}-0.2 \\
4\end{array}$ & 0.49 & 0.85 & 0.17 & $\begin{array}{l}-0.2 \\
8\end{array}$ & 1.00 & $\begin{array}{l}0.2 \\
5\end{array}$ & $\begin{array}{l}-0.5 \\
0\end{array}$ & 0.94 & $\begin{array}{l}0.1 \\
5\end{array}$ & $\begin{array}{l}-0.3 \\
8\end{array}$ \\
\hline Monthly rain & 0.14 & 0.34 & $\begin{array}{l}0.3 \\
1\end{array}$ & 0.10 & 0.16 & -0.05 & 0.22 & $\begin{array}{l}-0.1 \\
4\end{array}$ & 0.17 & 0.25 & $\begin{array}{l}1.0 \\
0\end{array}$ & 0.30 & 0.24 & $\begin{array}{l}0.5 \\
7\end{array}$ & 0.22 \\
\hline $\begin{array}{l}\text { Monthly mean } \\
\text { humidity }\end{array}$ & -0.42 & -0.35 & $\begin{array}{l}0.1 \\
1\end{array}$ & 0.52 & 0.48 & -0.33 & -0.43 & $\begin{array}{l}-0.3 \\
7\end{array}$ & 0.56 & -0.50 & $\begin{array}{l}0.3 \\
0\end{array}$ & 1.00 & -0.47 & $\begin{array}{l}0.1 \\
7\end{array}$ & 0.77 \\
\hline $\begin{array}{l}\text { Weekly mean } \\
\text { temperature }\end{array}$ & 0.85 & 0.83 & $\begin{array}{l}0.0 \\
3\end{array}$ & $\begin{array}{l}-0.3 \\
0\end{array}$ & $\begin{array}{l}-0.3 \\
1\end{array}$ & 0.56 & 0.91 & 0.24 & $\begin{array}{l}-0.3 \\
5\end{array}$ & 0.94 & $\begin{array}{l}0.2 \\
4\end{array}$ & $\begin{array}{l}-0.4 \\
7\end{array}$ & 1.00 & $\begin{array}{l}0.0 \\
5\end{array}$ & $\begin{array}{l}-0.4 \\
8\end{array}$ \\
\hline Weekly rain & -0.03 & 0.20 & $\begin{array}{l}0.5 \\
2\end{array}$ & 0.09 & 0.28 & -0.17 & 0.06 & $\begin{array}{l}-0.2 \\
7\end{array}$ & 0.27 & 0.15 & $\begin{array}{l}0.5 \\
7\end{array}$ & 0.17 & 0.05 & $\begin{array}{l}1.0 \\
0\end{array}$ & 0.38 \\
\hline $\begin{array}{l}\text { Weekly mean } \\
\text { humidity }\end{array}$ & -0.46 & -0.30 & $\begin{array}{l}0.2 \\
3\end{array}$ & 0.54 & 0.65 & -0.41 & -0.44 & $\begin{array}{l}-0.5 \\
4\end{array}$ & 0.72 & -0.38 & $\begin{array}{l}0.2 \\
2\end{array}$ & 0.77 & -0.48 & $\begin{array}{l}0.3 \\
8\end{array}$ & 1.00 \\
\hline
\end{tabular}

\begin{tabular}{llllll}
\hline $\mathrm{b}$ & Weekly.temperature & Daily.rain & Weekly.rain & Monthly.rain & Daily.humidity \\
\hline Daily.rain & 0.08493754 & & & & \\
Weekly.rain & 0.08743837 & 0.42208481 & & \\
Monthly.rain & 0.26051738 & 0.31221618 & 0.56875537 & \\
Daily.humidity & -0.30298379 & 0.32042834 & 0.26668608 & 0.1688703
\end{tabular}


Table S2. Temporal traits and climatic drivers of amphibian abundances at the Betampona reserve (Madagascar). We give the best climatic predictors, their relative importance $\Sigma w i$, and their coefficient and standard error (SE). Coefficients and standard errors were standardized and were obtained from full averaged parameters of a 'best model set' $(\triangle \mathrm{AICc}<2)$. Only variables with $\Sigma w i>0.6$ are shown. Variables with a significant effect that is robust to model selection uncertainty are shown in bold. All models accounted for the effect of site, transect topography, observer groups and the year of observation. Tests are relative to the 'Early spring' level (except when early spring is included: tests are relative to the remaining levels; $\left(^{*}\right) p \leq 0.1{ }^{*} p \leq 0.05 ; * * p \leq 0.01 ; * * *$ $p \leq 0.001)$. Models did not converge for the following rare species, which are not shown in this table: Boophis albipunctatus, Boophis sp. aff. fayi Betampona, Plethodonthohyla laevis, Guibemantis sp. aff. bicalcaratus Betampona£, Gephyromantis moseri, Stumpffia pardus, Guibemantis pulcher, Mantella nigricans, Boophis viridis, Mantella ebenaui, Mantidactylus aerumnalis, Platypelis sp. Ca1£ and Rhombophryne coudreaui. £, two or more genetic lineages morphologically and ecologically very similar.

\begin{tabular}{|c|c|c|c|c|c|c|c|}
\hline \multirow[b]{2}{*}{ Species } & \multirow{2}{*}{$\begin{array}{l}\text { Tot } \\
\text { al } \\
\text { cou } \\
\text { nt }\end{array}$} & \multirow{2}{*}{$\begin{array}{l}\text { Activit } \\
\mathrm{y} \\
\text { duratio }\end{array}$} & \multirow{2}{*}{$\begin{array}{l}\text { Season(s) with the } \\
\text { highest activity }\end{array}$} & \multicolumn{4}{|c|}{ Best climatic predictors } \\
\hline & & & & Variable & $\begin{array}{l}\Sigma w \\
i\end{array}$ & $\begin{array}{l}\text { Coeffi } \\
\text { cient }\end{array}$ & $\mathrm{SE}$ \\
\hline $\begin{array}{l}\text { Gephyromantis sp. Ca25 aff. } \\
\text { boulengeri }\end{array}$ & $\begin{array}{l}60 \\
51\end{array}$ & $\begin{array}{l}\text { Contin } \\
\text { uous }\end{array}$ & $\begin{array}{l}\text { Early spring***, Late } \\
\text { spring***, } \\
\text { Summer } * * *\end{array}$ & - & & & \\
\hline $\begin{array}{l}\text { Mantidactylus sp. Ca44 aff, } \\
\text { femoralis } £\end{array}$ & $\begin{array}{l}44 \\
80\end{array}$ & $\begin{array}{l}\text { Contin } \\
\text { uous }\end{array}$ & $\begin{array}{l}\text { Winter***, Early } \\
\text { spring*** }\end{array}$ & - & & & \\
\hline $\begin{array}{l}\text { Gephyromantis sp. Ca20 aff. } \\
\text { luteus }\end{array}$ & $\begin{array}{l}22 \\
49\end{array}$ & $\begin{array}{l}\text { Contin } \\
\text { uous }\end{array}$ & $\begin{array}{l}\text { Winter***, Early } \\
\text { spring** }\end{array}$ & Daily rain & $\begin{array}{l}1.0 \\
0\end{array}$ & 0.16 & $\begin{array}{l}0.0 \\
5\end{array}$ \\
\hline & & & & $\begin{array}{l}\text { Temperat } \\
\text { ure } \\
\text { Monthly } \\
\text { humidity }\end{array}$ & $\begin{array}{l}\mathbf{1 . 0} \\
\mathbf{0} \\
0.8 \\
5\end{array}$ & $\begin{array}{l}-\mathbf{0 . 2 8} \\
-0.12\end{array}$ & $\begin{array}{l}\mathbf{0 . 0} \\
6 \\
0.0 \\
8\end{array}$ \\
\hline $\begin{array}{l}\text { Gephyromantis redimitus } \\
\text { Betampona }\end{array}$ & $\begin{array}{l}20 \\
01\end{array}$ & $\begin{array}{l}\text { Contin } \\
\text { uous }\end{array}$ & Winter*** & - & & & \\
\hline
\end{tabular}




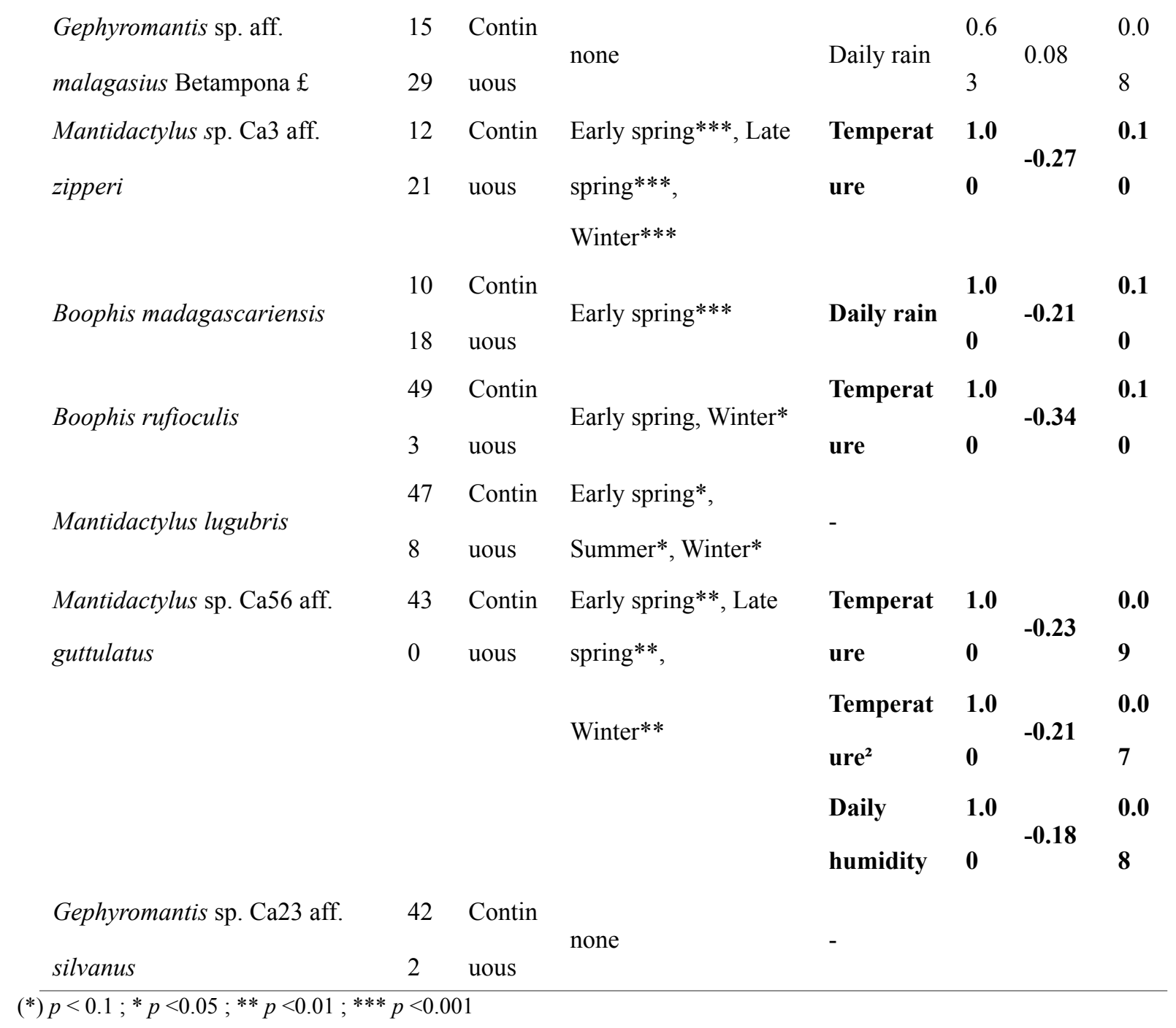


Table S2. Continued.

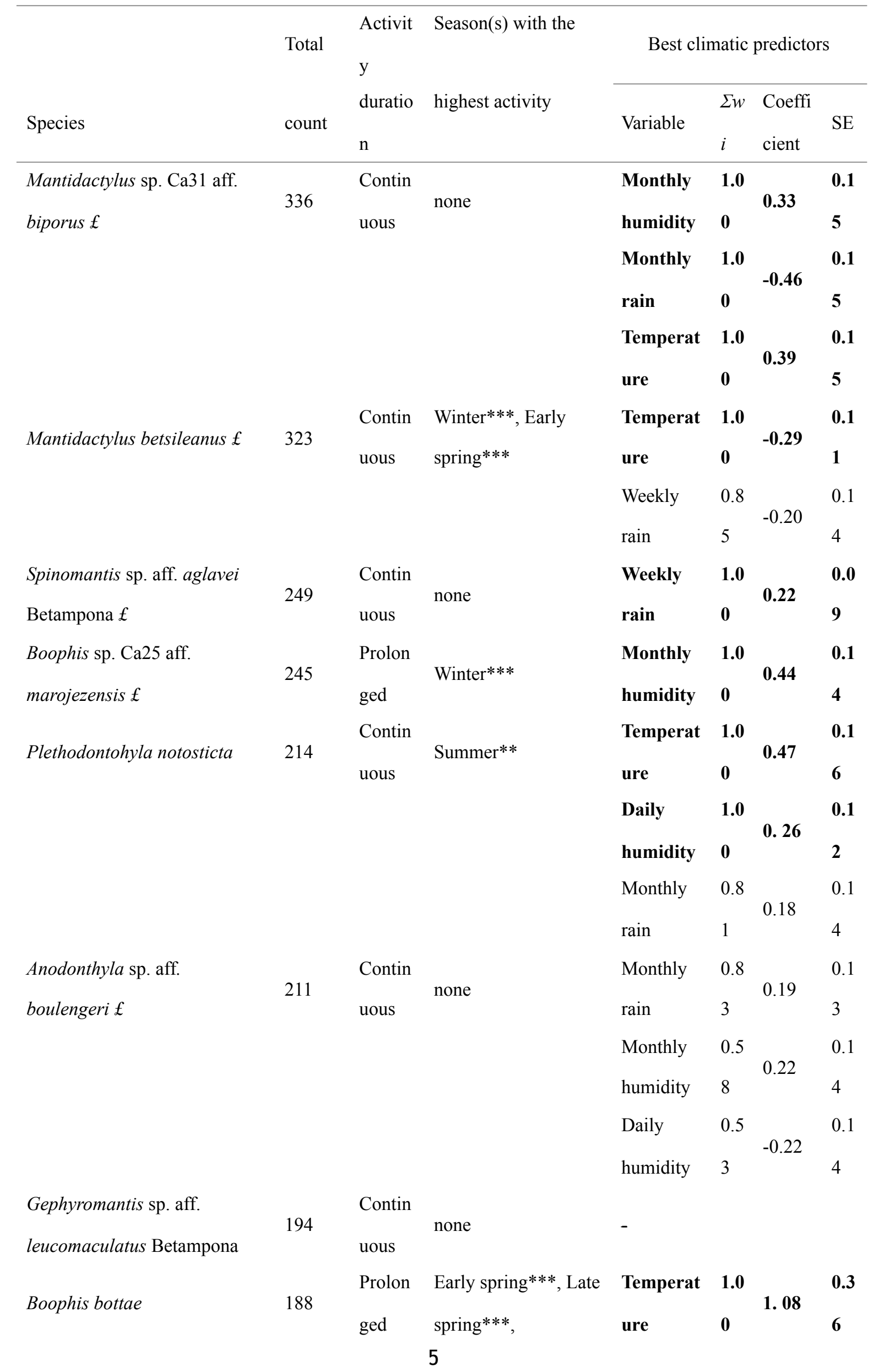


Summer***

\begin{tabular}{|c|c|c|c|c|c|c|c|}
\hline Platypelis karenae & 133 & $\begin{array}{l}\text { Prolon } \\
\text { ged }\end{array}$ & $\begin{array}{l}\text { Late spring**, } \\
\text { Summer*** }\end{array}$ & $\begin{array}{l}\text { Monthly } \\
\text { rain }\end{array}$ & $\begin{array}{l}1.0 \\
0\end{array}$ & 0.35 & $\begin{array}{l}0.1 \\
4\end{array}$ \\
\hline $\begin{array}{l}\text { Mantidactylus sp. Ca55 aff. } \\
\text { grandidieri }\end{array}$ & 131 & $\begin{array}{l}\text { Contin } \\
\text { uous }\end{array}$ & Winter* & - & & & \\
\hline Boophis roseipalmatus & 95 & $\begin{array}{l}\text { Prolon } \\
\text { ged }\end{array}$ & none & - & & & \\
\hline Platypelis grandis $£$ & 91 & $\begin{array}{l}\text { Contin } \\
\text { uous }\end{array}$ & none & $\begin{array}{l}\text { Monthly } \\
\text { rain }\end{array}$ & $\begin{array}{l}1.0 \\
0\end{array}$ & 0.35 & $\begin{array}{l}0.1 \\
0\end{array}$ \\
\hline Boophis albilabris & 78 & $\begin{array}{l}\text { Sporad } \\
\text { ic }\end{array}$ & Summer*** & $\begin{array}{l}\text { Weekly } \\
\text { rain }\end{array}$ & $\begin{array}{l}1.0 \\
0\end{array}$ & 0.62 & $\begin{array}{l}0.2 \\
1\end{array}$ \\
\hline & & & & $\begin{array}{l}\text { Temperat } \\
\text { ure }\end{array}$ & $\begin{array}{l}1.0 \\
0\end{array}$ & -0.57 & $\begin{array}{l}0.2 \\
8\end{array}$ \\
\hline & & & & $\begin{array}{l}\text { Daily } \\
\text { humidity }\end{array}$ & $\begin{array}{l}1.0 \\
0\end{array}$ & -0.65 & $\begin{array}{l}0.2 \\
6\end{array}$ \\
\hline $\begin{array}{l}\text { Mantidactylus sp. aff. } \\
\text { melanopleura }\end{array}$ & 68 & $\begin{array}{l}\text { Prolon } \\
\text { ged }\end{array}$ & none & Daily rain & $\begin{array}{l}0.6 \\
2\end{array}$ & 0.14 & $\begin{array}{l}0.1 \\
5\end{array}$ \\
\hline
\end{tabular}


Table S2. Continued.

\begin{tabular}{|c|c|c|c|c|c|c|c|}
\hline \multirow[b]{2}{*}{ Species } & \multirow{2}{*}{$\begin{array}{l}\text { Total } \\
\text { count }\end{array}$} & $\begin{array}{l}\text { Activit } \\
\mathrm{y} \\
\text { duratio }\end{array}$ & Season(s) with the & \multicolumn{4}{|c|}{ Best climatic predictors } \\
\hline & & $\begin{array}{l}\text { duratio } \\
\mathrm{n}\end{array}$ & highest activity & Variable & $\begin{array}{l}\Sigma w \\
i\end{array}$ & $\begin{array}{l}\text { Coeffi } \\
\text { cient }\end{array}$ & SE \\
\hline Platypelis barbouri $£$ & 58 & $\begin{array}{l}\text { Contin } \\
\text { uous }\end{array}$ & none & $\begin{array}{l}\text { Monthly } \\
\text { humidity }\end{array}$ & $\begin{array}{l}1.0 \\
0\end{array}$ & -0.41 & $\begin{array}{l}0.1 \\
6\end{array}$ \\
\hline $\begin{array}{l}\text { Blommersia sp. Ca13 aff. } \\
\text { grandisonae }\end{array}$ & 54 & $\begin{array}{l}\text { Contin } \\
\text { uous }\end{array}$ & Winter $(*)$ & $\begin{array}{l}\text { Monthly } \\
\text { humidity }\end{array}$ & $\begin{array}{l}1.0 \\
0\end{array}$ & 0.62 & $\begin{array}{l}0.2 \\
3\end{array}$ \\
\hline & & & & $\begin{array}{l}\text { Monthly } \\
\text { rain } \\
\text { Daily rain }\end{array}$ & $\begin{array}{l}1.0 \\
0 \\
0.8 \\
3\end{array}$ & -0.60 & $\begin{array}{l}0.2 \\
7 \\
0.2 \\
4\end{array}$ \\
\hline Platypelis tuberifera & 51 & $\begin{array}{l}\text { Prolon } \\
\text { ged }\end{array}$ & $\begin{array}{l}\text { Early spring*, Late } \\
\text { spring*, } \\
\text { Summer* }\end{array}$ & $\begin{array}{l}\text { Monthly } \\
\text { rain }\end{array}$ & $\begin{array}{l}0.8 \\
7\end{array}$ & 0.36 & $\begin{array}{l}0.2 \\
2\end{array}$ \\
\hline $\begin{array}{l}\text { Boophis sp. aff. luteus } \\
\text { Betampona }\end{array}$ & 40 & $\begin{array}{l}\text { Prolon } \\
\text { ged }\end{array}$ & none & $\begin{array}{l}\text { Monthly } \\
\text { humidity }\end{array}$ & $\begin{array}{l}0.8 \\
3\end{array}$ & 0.58 & $\begin{array}{l}0.4 \\
2\end{array}$ \\
\hline Blommersia angolafa & 38 & $\begin{array}{l}\text { Prolon } \\
\text { ged }\end{array}$ & Summer $(*)$ & Temperature & $\begin{array}{l}0.7 \\
9\end{array}$ & 0.43 & $\begin{array}{l}0.3 \\
5\end{array}$ \\
\hline Stumpffia betampona & 32 & Rare & none & - & & & \\
\hline $\begin{array}{l}\text { Boophis sp. aff pyrrhus } \\
\text { Sahavontsira }\end{array}$ & 29 & Rare & none & $\begin{array}{l}\text { Daily } \\
\text { humidity }\end{array}$ & $\begin{array}{l}1.0 \\
0\end{array}$ & 2.00 & $\begin{array}{l}0.6 \\
9\end{array}$ \\
\hline & & & & Temperature & $\begin{array}{l}0.6 \\
6\end{array}$ & 0.83 & $\begin{array}{l}0.7 \\
8\end{array}$ \\
\hline Stumpffia jeannoeli & 26 & $\begin{array}{l}\text { Contin } \\
\text { uous }\end{array}$ & Winter $(*)$ & $\begin{array}{l}\text { Monthly } \\
\text { humidity }\end{array}$ & $\begin{array}{l}1.0 \\
0\end{array}$ & 0.97 & $\begin{array}{l}0.3 \\
7\end{array}$ \\
\hline & & & & $\begin{array}{l}\text { Monthly } \\
\text { rain }\end{array}$ & $\begin{array}{l}0.8 \\
1\end{array}$ & -0.39 & $\begin{array}{l}0.3 \\
3\end{array}$ \\
\hline Mantidactylus albofrenatus $£$ & 24 & $\begin{array}{l}\text { Contin } \\
\text { uous }\end{array}$ & none & $\begin{array}{l}\text { Monthly } \\
\text { rain }\end{array}$ & $\begin{array}{l}0.8 \\
7\end{array}$ & 0.61 & $\begin{array}{l}0.3 \\
9\end{array}$ \\
\hline & & & & Temperature & $\begin{array}{l}0.8 \\
7\end{array}$ & -0.66 & $\begin{array}{l}0.4 \\
3\end{array}$ \\
\hline & & & & $\begin{array}{l}\text { Monthly } \\
\text { humidity }\end{array}$ & $\begin{array}{l}0.7 \\
5\end{array}$ & -0.58 & $\begin{array}{l}0.4 \\
6\end{array}$ \\
\hline
\end{tabular}




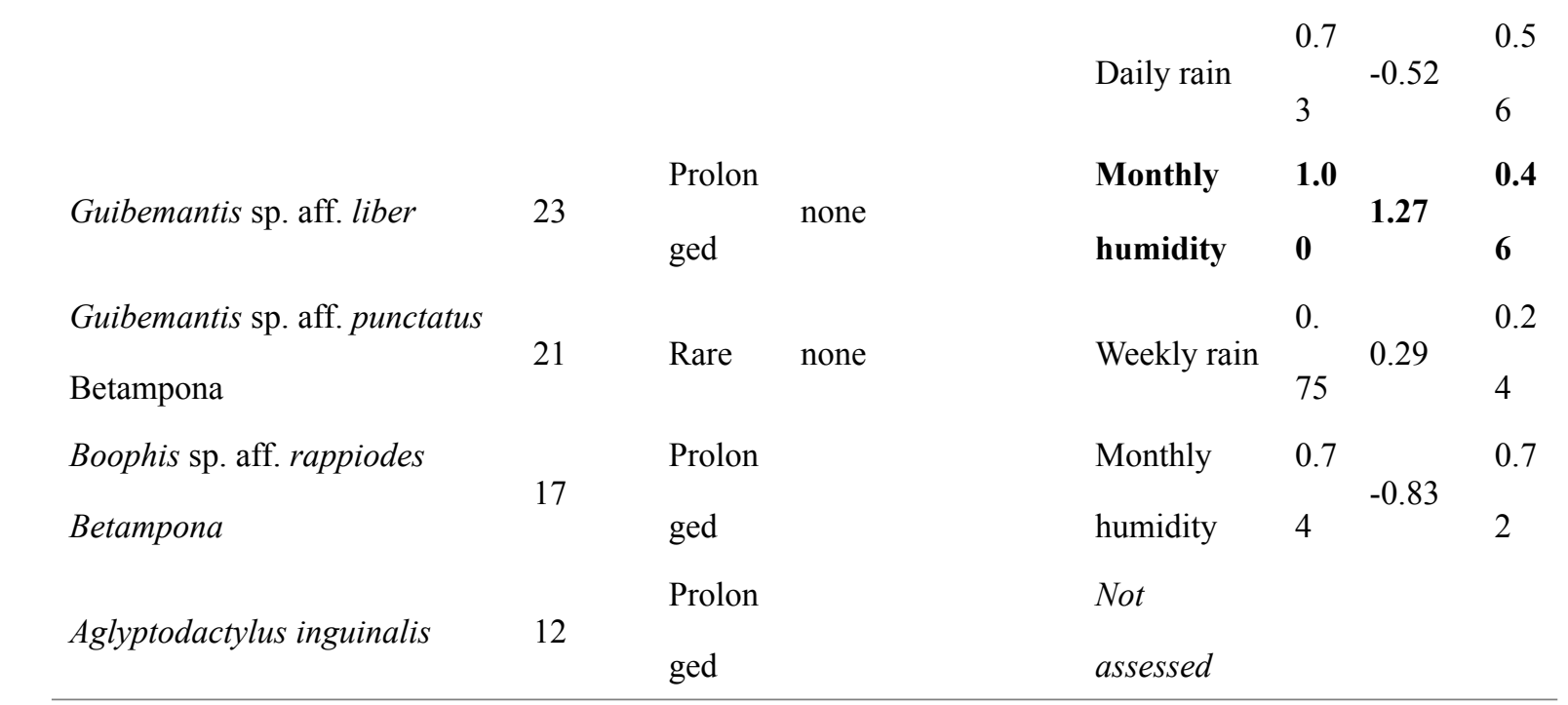

$\left(^{*}\right) p<0.1 ; * p<0.05 ; * * p<0.01 ; * * * p<0.001$. 


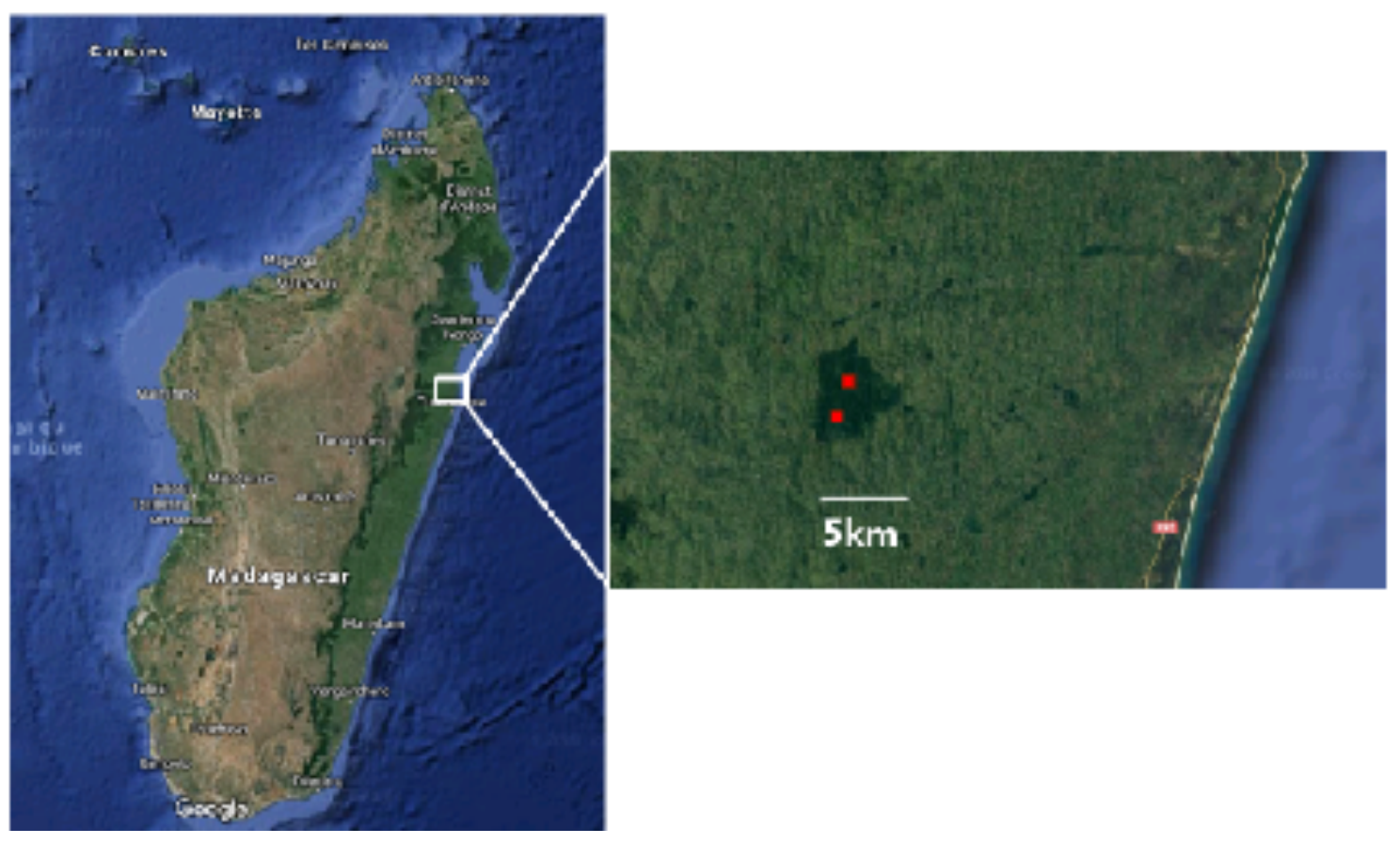

Fig. S1. Location of The Betampona Strict Nature Reserve with the two study sites (red squares; top: Sahambendrana, bottom: Sahabefoza) 

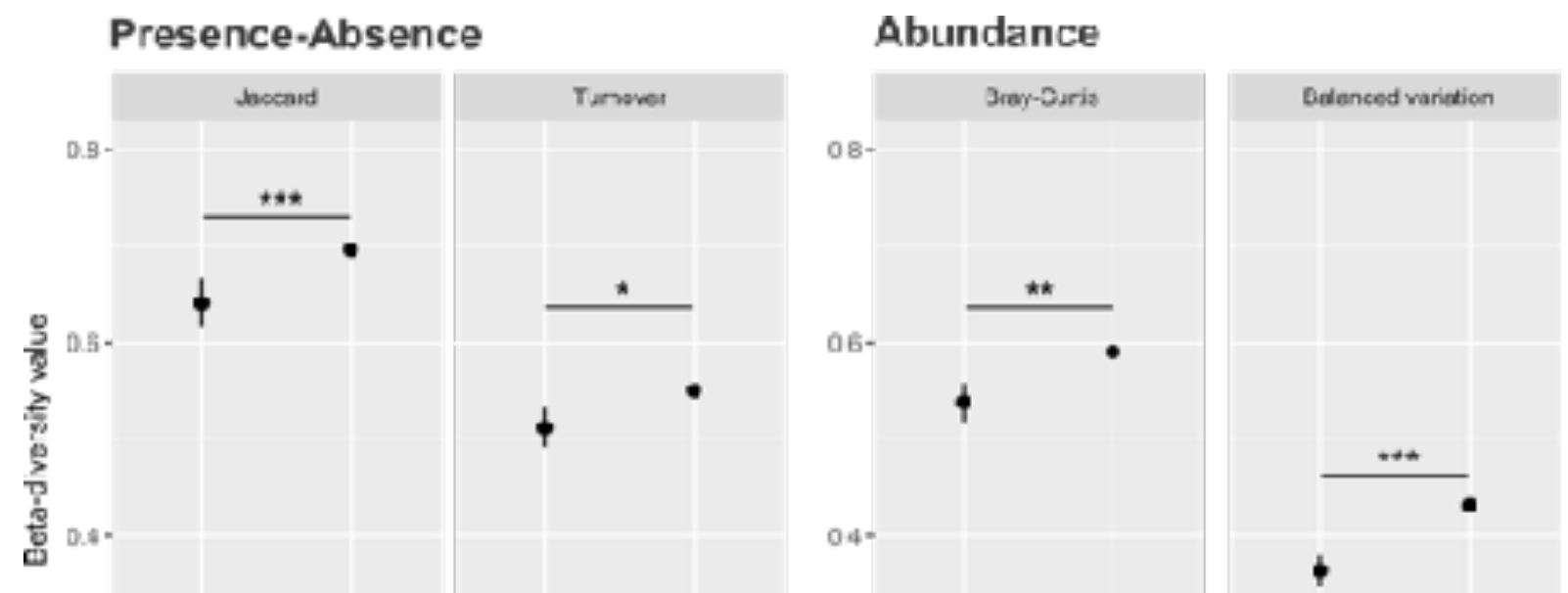

Fig. S2. Differences in within- and between-years temporal beta-diversity of the amphibian

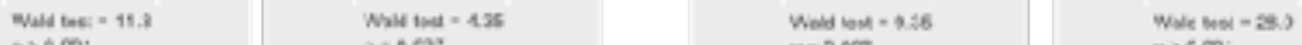
communities sampled in Betampona forest from 2009 to 2017 . Overall beta-diversity (on the Wikin yoare Betueón yoars Wihnysars Bctweón yoars

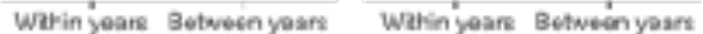
left) and its turnover components (on the right) were assessed, for both presence-absence (Jaccard dissimilarity) and abundance data (Bray-Curtis dissimilarity). Values are means \pm standard errors of the multisite dissimilarities ( 9 years x 6 transects for the within-years betadiversity; 36 years-combinations x 6 transects for the between-years beta-diversity). ${ }^{*} p \leq$ $0.05 ; * * p \leq 0.01 ; * * * p \leq 0.001$
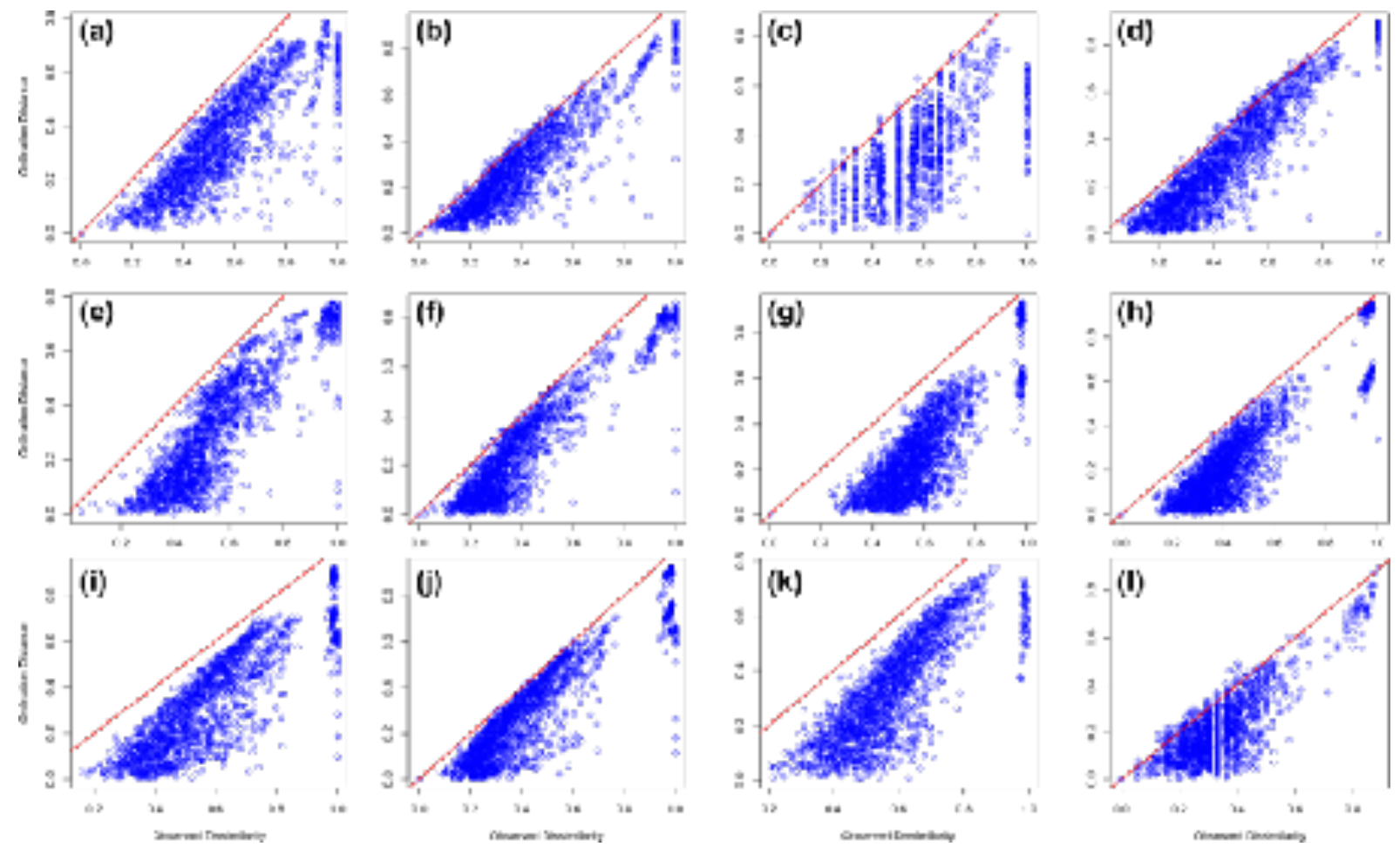
Fig. S3. Shepard's diagrams showing the goodness of fit of the measured pairwise dissimilarities of the amphibian communities (Jaccard and Bray-Curtis indices) as compared to the pairwise dissimilarities represented by MDS ordinations, for each position sampled within each transect (ridge on the top, slope in the middle and stream below) of the two sites (the two first column concern Sahambendrana, the two others Sahabefoza). 

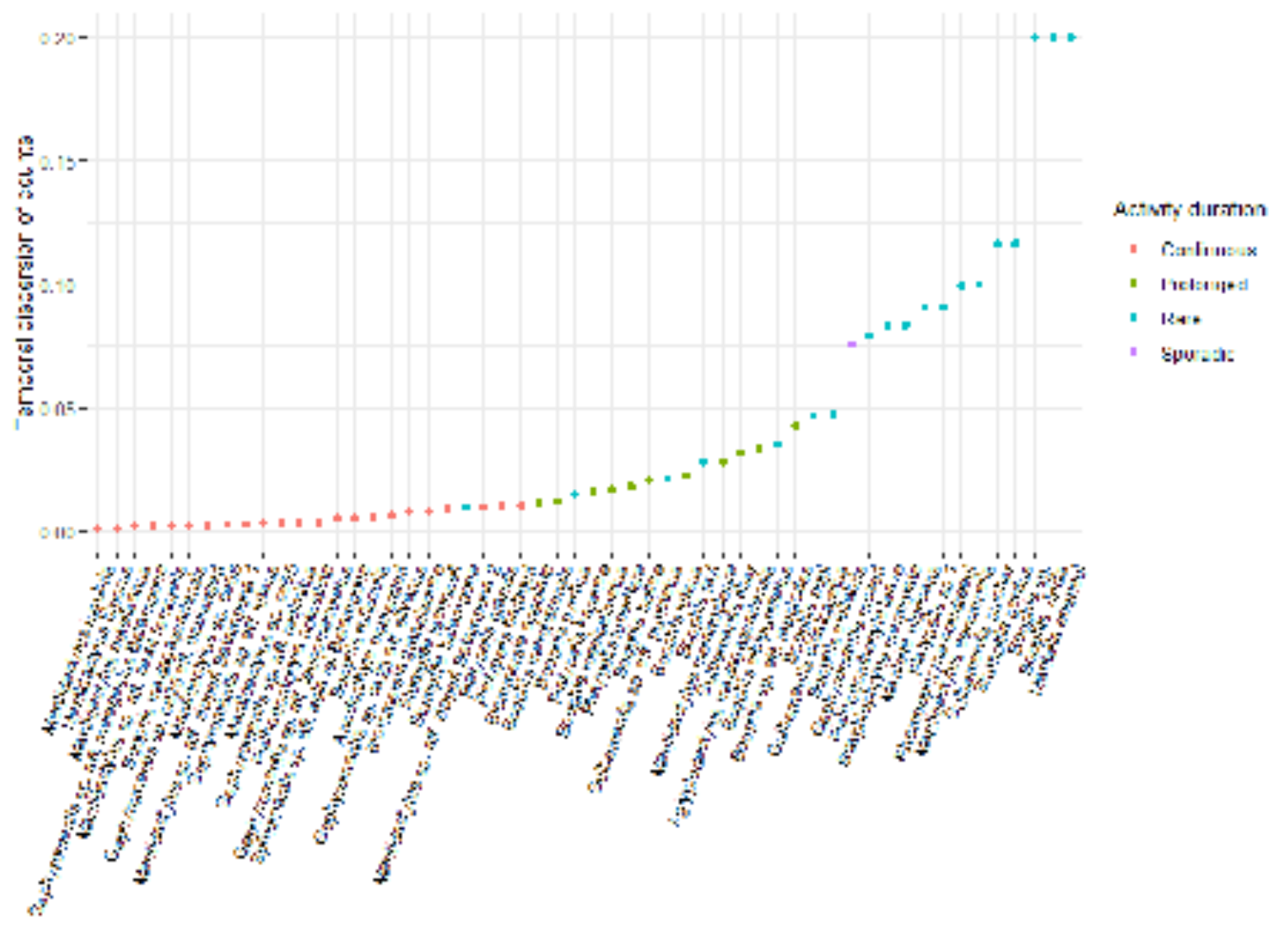

tiperes

Fig. S4. Temporal dispersion of counts (variance of monthly abundances, $p$ ) for 54 amphibian species from Betampona (left panel), and distribution frequencies of $p$ (right panel, rare species are excluded). Species' breeding duration is classified according to the modality into which $p$ is included. Continuous breeders: $p>0.01$; Prolonged breeders: $0.01<p>0.05$; Explosive breeders: $p<0.05$. 